\title{
An Analysis of Recent Studies of the Effect of Foreign Exchange Intervention
}

\author{
Christopher J. Neely
}

\begin{abstract}
Two recent strands of research have contributed to our understanding of the effects of foreign exchange intervention: (i) the use of high-frequency data and (ii) the use of event studies to evaluate the effects of intervention. This article surveys recent empirical studies of the effect of foreign exchange intervention and analyzes the implicit assumptions and limitations of such work. After explicitly detailing such drawbacks, the paper suggests ways to better investigate the effects of intervention.
\end{abstract}

Federal Reserve Bank of St. Louis Review, November/December 2005, 87(6), pp. 685-717.

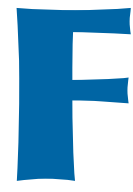

oreign exchange intervention is the practice of monetary authorities buying and selling currency in the foreign exchange market to influence exchange rates. Researchers have studied whether intervention is successful in influencing exchange rate movements and how it affects volatility. Secondarily, they have asked how the type of intervention affects these results and through which channels it might operate.

Intervention has several characteristics that complicate one's ability to study it. It is conducted sporadically, with several interventions over the course of a few days or weeks. Thus, it has an unusual distribution. Intervention policy is rarely stable for long periods. Finally, because intervention quickly reacts to exchange rate movements and other variables, exchange rates and intervention are determined simultaneously. These problems have made it difficult to show that central bank intervention has reduced exchange rate volatility or moved the exchange rate in the desired direction. Yet, every central banker surveyed in Neely (2000)—-those who actually conduct intervention-remains con- vinced that intervention is effective in changing the exchange rate. ${ }^{1}$

Recently two phenomena have advanced our understanding of intervention. The first is the use of event studies to evaluate the effects of intervention. Generically, an event study is an examination of asset price behavior associated with some event, such as a merger, announcement, or intervention. Event studies are used to assess the market's reaction to the event, how the event influenced prices, and whether the market priced the event efficiently. The second advance is the use of high-frequency data-both exchange rates and intervention-to better understand the behavior of exchange rates immediately around intervention.

Despite these advances, inferring the effects of central bank intervention remains difficult. Although describing the data is a worthy and necessary goal, explaining the nature of the process by which exchange rates and intervention

1 Neely (2000) received responses from the central banks of Belgium, Brazil, Canada, Chile, the Czech Republic, Denmark, France, Germany, Hong Kong, Indonesia, Ireland, Italy, Japan, Mexico, New Zealand, Poland, South Korea, Spain, Sweden, Switzerland, Taiwan, and the United States. 
are jointly determined requires strong assumptions, which are rarely explicitly stated. While many intervention researchers are doubtless cognizant of such issues, those less familiar with the literature are probably not well aware of them. The purpose of this article is to selectively review the recent literature on the effects of intervention and to analyze the assumptions and limitations of such exercises. ${ }^{2}$ Identifying the assumptions and limitations of the intervention literature is not to condemn those procedures. Rather such recognition enables the limitations to be better understood and overcome. This paper does not expend much effort describing the disparate conclusions of the literature. The appendix summarizes such conclusions and specific methods for interested readers.

This article first discusses central bank intervention practices and explains how researchers typically study intervention. Selected intervention studies are then discussed. The fourth section considers the assumptions behind intervention studies, with a special emphasis on the often implicit assumptions behind the new event-study methodologies. In its conclusion, the article discusses the strengths and weaknesses of the methods of studying the effects of intervention and suggests avenues for future research.

\section{CENTRAL BANK INTERVENTION}

After the breakdown of the Bretton Woods system of fixed exchange rates in 1973, the Articles of the International Monetary Fund (IMF) were amended to provide that members "would collaborate with the Fund and other members to assure orderly exchange arrangements and to promote a stable system of exchange rates." IMF members could choose their own exchange rate arrangements subject to the proviso that they avoid exchange rate manipulation and foster orderly economic growth. Many countries choose to float their exchange rates and conduct occasional

\footnotetext{
2 This paper is a fairly narrow and selective survey of the intervention literature. Edison (1993), Sarno and Taylor (2001), and Humpage (2004) provide more wide-ranging treatments of intervention studies. The Bank for International Settlements (BIS) (2005) provides a range of views on intervention in emerging markets.
}

foreign exchange intervention to influence the value of their currencies. ${ }^{3}$

Central banks choose to intervene for different reasons. The Foreign Currency Directive of the Federal Reserve System, for example, directs intervention to "counter disorderly market conditions," which has been interpreted differently at different times. ${ }^{4}$ Often, excessive exchange rate volatility or deviations from long-run equilibrium exchange rates have prompted intervention.

Multiple central banks often coordinate intervention, intervening in the same direction on the same day.

The response rule of central bank intervention to economic conditions is known as the central bank's intervention reaction function. Neely (2002) estimates a typical reaction function for U.S. intervention with a friction model. A friction model permits the dependent variable-intervention-to be insensitive to its determinants over a range of values (Rosett, 1959). This is appropriate for a variable such as intervention that takes the value zero for a large proportion of observations. The study confirms previous findings that U.S. intervention "leans against the wind" and is conducted to counter misalignment. Leaning-againstthe-wind intervention is conducted to oppose strong short-term trends. For example, if the U.S. dollar (USD) has been depreciating, a USD purchase would constitute leaning against the wind. Misalignment means that the exchange rate deviates from what the monetary authorities might regard as long-run fundamentals, such as those implied by a purchasing power parity relation.

Figure 1 shows U.S. intervention in the Deutsche mark (DEM) market, as well as the exchange rate, compared with a purchasing power

\footnotetext{
3 In the United States, for example, the Federal Reserve and the U.S. Treasury generally collaborate on foreign exchange intervention decisions, and the Federal Reserve Bank of New York conducts operations on behalf of both. Humpage (1994) and Cross (1998) describe the institutional aspects of U.S. intervention, whereas Edison (1993) reviews the extensive literature on central bank intervention.

4 The directive mandates intervention in cooperation with foreign central banks, consistent with International Monetary Fund Article IV, Section 1, that forbids attempts to remedy balance-ofpayments problems by manipulating exchange rates. "The Foreign Currency Directive" is published annually in the Federal Reserve Bulletin with the minutes of the first Federal Open Market Committee meeting of each year.
} 


\section{Figure 1}

\section{Intervention, Exchange Rates, and Purchasing Power Parity Fundamentals}
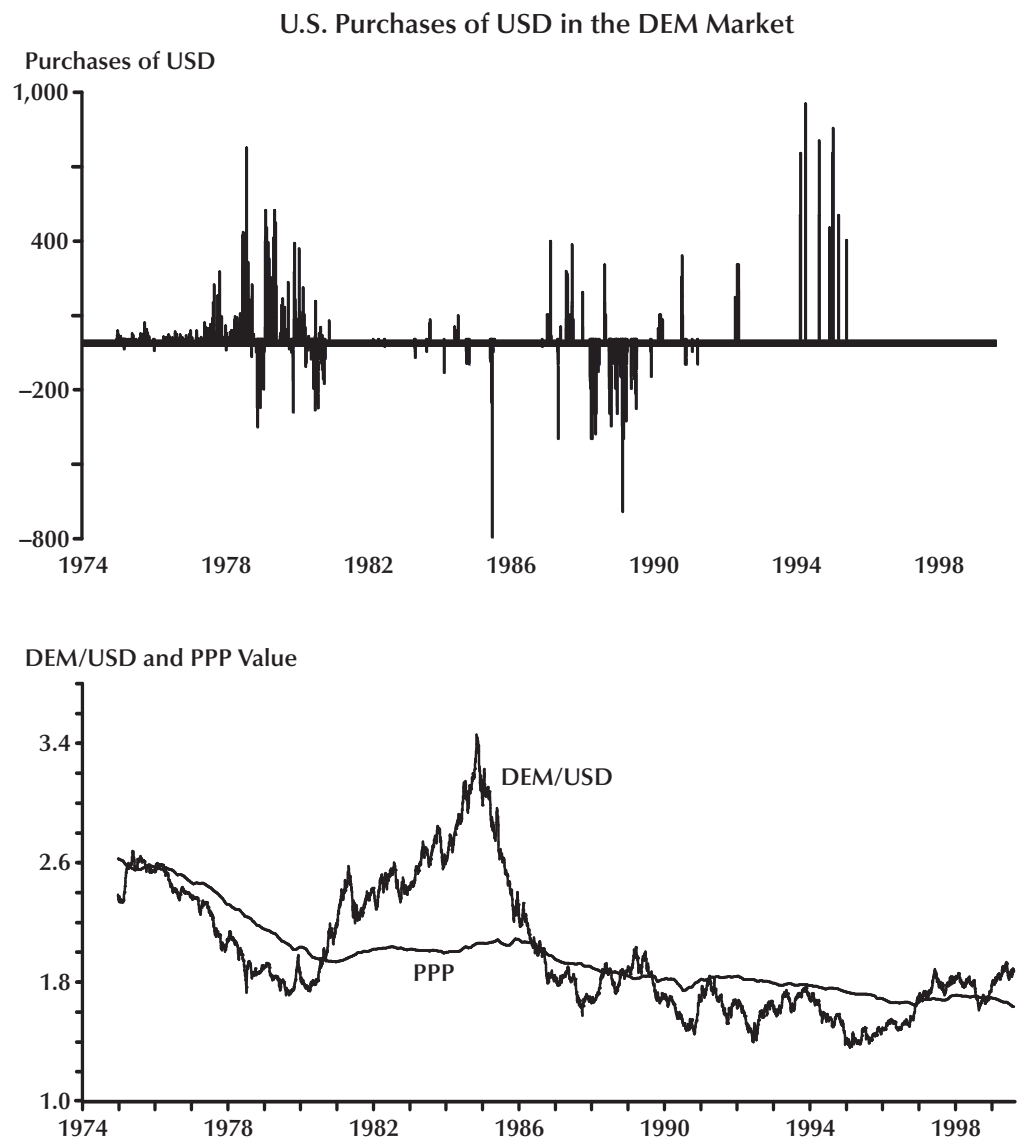

parity-based fundamental value. Statistical analysis confirms the impression that U.S. authorities tend to purchase USD when the USD is relatively undervalued and sell USD in the reverse circumstance. Leahy (1995) and Neely (1998) find that U.S. authorities make substantial profits as a result of this intervention strategy. ${ }^{5}$

When a central bank buys (sells) its own currency in exchange for a foreign currency, it decreases (increases) the amount of its currency in circulation, lowering (raising) its domestic money supply. By itself, this transaction would

${ }^{5}$ Although U.S. authorities-as with those of many other countrieshave profited from their foreign exchange intervention activities, this does not mean that profit is the goal of those trades; it is merely a side benefit. influence exchange rates in the same way as ordinary domestic open market operations; however, most central banks routinely "sterilize" their foreign exchange operations; that is, they buy and sell domestic bonds to reverse the effect of the foreign exchange operation on the domestic money supply (Edison, 1993). ${ }^{6}$ For example, if the Federal Reserve Bank of New York bought $\$ 100$ million worth of euros (EUR) in a foreign exchange intervention, the U.S. monetary base would increase by $\$ 100$ million in the absence of sterilization. Other things equal, interest rates and prices would also change. To prevent changes

6 Conducting monetary policy by way of a short-term interest rate target automatically sterilizes intervention. 
to domestic interest rates and prices, the Federal Reserve Bank of New York would sterilize the intervention-sell $\$ 100$ million worth of government securities-and absorb the liquidity. Complete sterilization would also require that the foreign central bank-the European Central Bank (ECB) in the case of the EUR-automatically reverse the effect of the intervention on the foreign money market by increasing the supply of foreign currency through open market operations. The net effect would be to increase the relative supply of U.S. government securities versus foreign securities but to leave domestic and foreign money supplies unchanged.

Because fully sterilized intervention doesn't affect either prices or interest rates, it doesn't influence the exchange rate directly. But official intervention might affect the foreign exchange market indirectly through the portfolio balance channel and/or the signaling channel.

The portfolio balance theory recognizes that sterilized intervention changes the relative supplies of bonds denominated in different currencies. If bonds in different currencies are imperfect substitutes, investors must be compensated with a higher expected return to hold the relatively more numerous bonds. The higher return must result from a change in either the price of the bonds or the exchange rate.

The signaling channel suggests that official intervention communicates, or signals to the market, information about future monetary policy or the long-run equilibrium value of the exchange rate. Complicating a belief in the signaling channel is the fact that central banks often conduct intervention secretly. In fact, 77 percent of central banks report that they sometimes or always conduct intervention secretly to maximize market impact (Neely, 2000).

\section{ESTIMATING THE EFFECTS OF INTERVENTION}

The most important questions confronting researchers on intervention are as follows: What effect does intervention have on the level and volatility of exchange rates? To what conditions do central banks respond? Secondarily, how do factors such as coordination, direction, secrecy, and the amount of intervention affect the answers to those questions?

Researchers have used at least three types of studies to investigate these questions: By far the most common type of study has been a time-series event study. More recently, researchers have pursued a different type of event study in which interventions are grouped into clusters and the effect of the cluster is considered as one event. These will be termed other event studies. Both types of event studies examine the behavior of exchange rates around intervention, without making explicit assumptions about the data-generating process. The third-and least common-type of study is an explicitly identified structural analysis of the effects of intervention. We briefly describe each of these procedures before proceeding to a literature review.

\section{Time-Series Event Studies}

Time-series event studies have a long history: Humpage (1984) and Dominguez and Frankel (1993) are two early efforts. Such studies typically investigate the effect of intervention on returns using a single equation in which intervention $\left(I_{t}\right)$ and a limited set of regressors explain the change in the exchange rate $\left(\Delta S_{t}\right)$ :

$$
\Delta S_{t}=C_{r}+\beta I_{t}+A x_{1 t}+e_{t},
$$

where $\left\{C_{r}, \beta, A\right\}$ is the coefficient vector, $S_{t}$ is units of foreign currency per unit of domestic currency, and the set of regressors $x_{1 t}$ might include interest rate differentials or macroeconomic news or other variables that might influence the exchange rate. How the data are timed is important in such regressions. Variables are usually defined so that intervention at time $t$ would occur during the exchange rate change of the same date. In other words, if exchange rates are collected at the end of the business day, $\Delta S_{t}=\ln S_{t} / S_{t-1}$, then intervention explains contemporaneous exchange rate changes. Such studies interpret the coefficient $\beta$ as the effect of intervention on exchange rate changes.

Recently, researchers have begun studying the effect of intervention on option-implied volatility 
(IV), implied skewness, kurtosis, and even correlations by using a regression setup similar to (1) (Campa and Chang, 1998). ${ }^{7}$ Such studies have most of the strengths and limitations of studies of the effect of intervention on returns.

The other common way to study the effect of intervention on volatility is with a GARCH $(1,1)$ model (Bollerslev, 1986) in which intervention and other variables can influence exchange rate conditional variance $\left(h_{t}\right)$ contemporaneously, as follows:

$$
h_{t}=\omega+\beta h_{t-1}+\alpha e_{t-1}^{2}+b_{I} I_{t} .
$$

Such specifications frequently also include lagged values of intervention and/or indicator variables for weekends and holidays as explanatory variables in the GARCH model. Again, studies interpret the coefficient on intervention $\left(b_{I}\right)$ as the effect of intervention on volatility.

Although it is not the subject of this paper, it is worth noting that there is also a large-and usually unconnected-literature estimating intervention reaction functions. Such studies usually describe intervention as a function of contemporaneous and past exchange rate changes and volatility, lagged intervention, and deviations from some exchange rate target:

(3) $I_{t}=\sum_{i=0}^{P} a_{i} \Delta S_{t-i}+\sum_{i=1}^{P} b_{i} I_{t-i}+c\left(S_{t}-\bar{S}_{t}\right)+d+v_{t}$.

Limited dependent variable frameworks, such as the friction model of Rosett (1959) or Tobin's (1958) Tobit model, are often applied to intervention because of its unusual distribution.

\section{Other Event Studies}

The second class of event study typically uses data only from around periods of intervention, ignoring the behavior of exchange rates when there is no intervention. Such studies provide a seemingly natural way to model the sporadic nature of intervention. As Fatum and Hutchison note,

\footnotetext{
7 Option-implied volatility, implied skewness, and implied kurtosis are measures of the second, third, and fourth moments of the distribution of the underlying asset that are obtained from options prices. Neely (2005c) discusses implied volatility in some detail.
}

An event study framework is better suited to the study of sporadic and intense periods of official intervention, juxtaposed with continuously changing exchange rates, than standard time-series studies. Focusing on daily Bundesbank and US official intervention operations, we identify separate intervention "episodes" and analyse the subsequent effect on the exchange rate. (Fatum and Hutchison, 2003b, p. 390)

To conduct an event study, one must define the events, a window around the event, a success criterion, and a method of evaluating the success criterion. Events might be defined as a single intervention or a series of interventions in the same direction within a short time. Windows are typically chosen to be from 1 to 30 days. The exchange rate behavior in the pre-event window is compared with exchange rate behavior in the post-event window.

Choosing an event window requires one to make trade-offs. Longer event windows permit researchers to judge the overall effect of related interventions. On the other hand, longer windows increase the danger of omitting important variables that influence exchange rates. Perhaps more seriously, monetary authorities might intervene until the exchange rate moves in the desired direction. Even if intervention has no influence on exchange rates, if the authority keeps intervening until it observes the desired outcome, then intervention appears to be successful. Longer event windows increase this danger.

Researchers have considered various success criteria. The most commonly used are the direction criterion and the smoothing criterion (Humpage, 2000). The direction criterion defines intervention as successful if the purchased currency appreciates after an intervention. That is, a USD purchase would be successful if the dollar appreciated in the post-event window. But, mindful that most intervention is "against the wind"- -that is, the authorities are buying the currency that is depreciating-one might also consider an official purchase to be successful if the purchased currency depreciates less in the post-event window than in the pre-event window. The standard that the intervention should moderate the pre-event trend 
in the exchange rate is known as the smoothing criterion.

Once the success criterion is defined, one needs some method to evaluate whether it has been achieved. In strictly narrative studies, the researcher might simply graph the data or compute simple summary statistics, such as the percentage of successes or mean change in the exchange rate, to informally judge whether intervention has been successful. Otherwise, one formally tests whether differences between pre- and post-event behavior are statistically significant.

Humpage (1999 and 2000), for example, examines whether one can reject that the observed number of exchange rate changes of a given type (e.g., depreciations) come from a null distribution. ${ }^{8}$ In other words, for example, does the Japanese yen (JPY) depreciate more often than one would expect when the Fed sells JPY for USD? The number of successes under the null of no effect is distributed as a hypergeometric random variable. Humpage goes on to test whether successful interventions are related to factors such as amount, coordination, and secrecy by regressing success indicators on those factors in a probit framework.

Fatum and Hutchison (2003a) similarly test whether the number of "successful" interventions is greater than one would expect if intervention were ineffective. And they use a "matched sample" $t$-test to ask whether the mean post-intervention exchange rate change is statistically significantly different from the mean pre-intervention change.

\section{STUDIES OF THE EFFECTS OF INTERVENTION}

Event studies have recently gained greater popularity, particularly those that consider a cluster of interventions as one event and/or use nonparametric methods to evaluate the success of those interventions. The difficulties of applying traditional structural econometric techniquessimultaneity, identification, the unusual distri-

\footnotetext{
8 Humpage's studies can be interpreted as time-series event studies in which the dependent variable is an indicator variable that depends on the behavior of exchange rates, conditional on intervention. Such tests use all the exchange rate data, not just data around interventions.
}

bution of intervention-have doubtless played a significant role in the rise of such studies. This section first enumerates some recent event studies before considering some explicitly identified investigations of intervention.

\section{Event Studies with Daily Data}

Many papers using daily intervention and exchange rate data describe themselves as event studies: Fatum and Hutchison (2003a,b) and Edison, Cashin, and Liang (2003). Other papers can reasonably be described as event studieseven though they do not use that term-because they characterize the behavior of exchange rates around periods of intervention, without explicitly identifying a structural relation: Humpage (1999, 2000), Aguilar and Nydalh (2000), Kim, Kortian, and Sheen (2000), Ito (2002), and Chaboud and Humpage (2005). Such studies provide mixed support for the hypothesis that intervention influences exchange rates in the desired direction and also mixed conclusions as to its effect on volatility. Coordinated interventions were usually found to be more successful than unilateral interventions.

\section{Intraday Event Studies}

More recently, a third group of papers have used intraday data to evaluate the behavior of exchange rates at very high frequencies around the times of intervention. Fischer and Zurlinden (1999), Payne and Vitale (2003), and Pasquariello (2002) have exploited the fact that the Swiss National Bank has released data on the exact times of intervention, not just the day and amount. Fischer and Zurlinden (1999) look at irregularly timed observations at times of intervention to examine the effects of intervention. Payne and Vitale (2003) use exchange rate data sampled at 15-minute intervals to quantify the effects of intervention operations on the U.S. dollar/Swiss franc (USD/CHF) rate. Pasquariello (2002) looks at a wider variety of exchange rate behaviorincluding spreads-in a similar exercise. Beattie and Fillion (1999) use confidential timed intervention data from the Bank of Canada to similarly investigate the intraday effects of Canadian inter- 
vention. Fatum and King (2005) compare the effects of Canadian intervention on high-frequency data over periods with both rule-based and discretionary intervention. They find that intervention does systematically affect the Canadian dollar/U.S. dollar (CAD/USD) rate and might be associated with reduced volatility. Finally, Dominguez (2003a,b) regresses 5-minute exchange rate returns and 5-minute volatility on leads and lags of news announcement and intervention news dummies-taken from Reuters reports, collected by Olsen and Associates-during days of U.S. intervention from 1987 to 1993. Dominguez interprets the coefficients on intervention and news dummies as showing the impact of those events on exchange rate behavior at that horizon. The consensus of these papers has been that interventions successfully move exchange rates, at least in the very short term.

\section{Identified Studies of Intervention}

Not all studies of intervention can be classified as event studies. Some explicitly model structural economic relations to identify the effect of intervention on exchange rate behavior. ${ }^{9}$ Three such studies are those of Kim (2003), Kearns and Rigobon (2005), and Neely (2005b).

Kim (2003), for example, estimates a structural vector autoregression (VAR) adapted from the monetary policy literature to examine the effects of intervention and monetary policy on a tradeweighted exchange rate. The monthly data span 1974:01- 1996:12 and include the ratio of foreign exchange intervention to a quadratic trend in the monetary base, the federal funds rate, monetary aggregates, the consumer price index, industrial production, the trade-weighted exchange rate, and commodity prices. The specification permits twoway contemporaneous interaction between intervention and exchange rates, the federal funds rate and the monetary aggregates, and the federal funds rate and commodity prices. The inclusion of

\footnotetext{
9 In models derived from a microeconomic optimization problem, the parameters are often termed "deep" structural parameters and will be invariant to changes in the economic environment. This paper uses the more traditional meaning of what are sometimes called pseudo-structural parameters-they have economic interpretations.
}

monetary policy measures and macro variables might mitigate the problem of omitted variables bias: If some independent variables are omitted from a relation, then one will generally not get consistent estimates of coefficients on correlated regressors. Unfortunately, the low-frequency monthly macro data will miss the important highfrequency interactions and complicates the task of sorting out the interaction between intervention and exchange rates. ${ }^{10}$ Thus, Kim (2003) estimates a rich set of macroeconomic relations and policy interactions, at the price of greater simultaneity bias and possibly noisier parameter estimates from lower-frequency data.

Neely (2005a) shows, however, that some parameters are not identified in Kim's (2003) study. Identification requires that one have at least as many estimable moments from the reduced form as there are structural parameters. But that is only a necessary condition (i.e., the order condition) to identify all the parameters; it is not sufficient. Unfortunately, the system fails the rank condition (Hamilton, 1994). A subset of the parametersincluding those governing the cross-reactions of exchange rates and intervention-appear to be unidentified. This calls the estimated impulse responses into question, though they might be interpreted as a set (not unique) of impulse responses that are consistent with the data.

Kearns and Rigobon (2005) perform an innovative study that takes advantage of structural breaks in the Japanese and Australian authorities' reaction functions to estimate a nonlinear model of intervention. ${ }^{11}$ The first equation describes the reaction of the exchange rate return to intervention, $I_{t}$, exogenous variables, $z_{t}$, and an exchange rate shock, $\varepsilon_{t}$ :

$$
\Delta S_{t}=\beta I_{t}+\gamma z_{t}+\varepsilon_{t} .
$$

The second equation is a central bank reaction function that describes the "shadow" intervention level, $I_{t}^{*}$, as a function of exchange rate changes $\left(\Delta S_{t}\right)$ and exogenous variables:

\footnotetext{
${ }^{10}$ Kim (2003) does make an effort to capture the higher-frequency interaction with a separate exercise.

11 This simplified version of the model suppresses constants and lags to facilitate the explanation of the identification scheme.
} 


$$
I_{t}^{*}=\delta \Delta S_{t}+z_{t}+\eta_{t}
$$

The third equation models the binary decision to intervene if shadow intervention exceeds some threshold. Ind $\left({ }^{*}\right)$ is an indicator function that equals 1 if its argument is true and 0 otherwise:

$$
I_{t}=\operatorname{Ind}\left(\left|I_{t}^{*}\right|>\bar{I}\right) \cdot I_{t}^{*} .
$$

This simplified model has seven parameters of interest $\left\{\beta, \gamma, \delta, \bar{I}, \sigma_{\varepsilon}, \sigma_{\eta}, \sigma_{z}\right\}$, but there are only five moments of the data: the probability of intervention, the variance of the exchange rate when there is no intervention, and the three elements of the covariance matrix when an intervention has taken place. Clearly, one cannot estimate seven independent structural parameters with five moments.

But, if one allows for the break in the threshold of intervention, then the threshold takes the low value, $\bar{I}_{l}$, prior to the break in the reaction function at $\hat{t}$ and the high value, $\bar{I}_{h}$, after the break. The intervention decision can be expressed as follows:

$$
I_{t}=\begin{array}{ll}
\operatorname{Ind}\left(\left|I_{t}^{*}\right|>\overline{I_{l}}\right) \cdot I_{t}^{*} & t<\hat{t} \\
\operatorname{Ind}\left(\left|I_{t}^{*}\right|>\overline{I_{h}}\right) \cdot I_{t}^{*} & t>\hat{t}
\end{array} .
$$

Allowing for the break in the reaction function and assuming that other structural parameters do not change after the break, the model has one more structural parameter- $\left\{\bar{I}_{l}, \bar{I}_{h}\right\}$ instead of $\{\bar{I}\}$-but one can compute 10 moments from the data: 5 from the pre-break period and 5 from the postbreak period. The system now can be identified. ${ }^{12}$

Kearns and Rigobon (2005) estimate the model by the simulated method of moments and interpret their estimates of $\beta$ as indicating that intervention has a large effect on the Australian dollar/U.S. dollar (AUD/USD) exchange rate and a smaller effect on the JPY/USD rate. The baseline model estimates that a sale of $\$ 100$ million is associated with a 1.81 percent AUD appreciation but just a 0.2 percent JPY appreciation. Kearns and Rigobon (2005) go on to calculate impulse response functions for more elaborate models, emphasizing the importance of estimating dynamic responses.

\footnotetext{
${ }^{12}$ Of course, even if one has more estimable moments from the data than parameters to estimate, that does not guarantee identification, but a lack of sufficient moments does preclude it.
}

Neely (2005b) identifies the cross-effects of intervention with the level and volatility of exchange rates using the likely timing of intervention, macroeconomic announcements as instruments, and the nonlinear structure of the U.S. intervention reaction function. Proper identification of the effects of intervention indicates that it is moderately effective in changing the levels of exchange rates but has no significant effect on volatility. The paper also illustrates that such inference depends on seemingly innocuous identification assumptions.

\section{ASSUMPTIONS BEHIND EVENT AND STRUCTURAL STUDIES OF INTERVENTION}

An important goal in studying intervention and exchange rate behavior is to ascertain the effect of intervention on exchange rates. An event study, by definition, looks at the behavior of an asset price (e.g., exchange rates) around periods of intervention. This does not necessarily mean, however, that intervention causes the exchange rate behavior. To determine the effect of intervention on exchange rates, one must consider how all the variables that influence exchange rates and intervention interact.

\section{A System of Exchange Rates and Intervention}

Consider a simple but general case (equation (8)) in which exchange rate returns and intervention potentially depend on one lag of returns and intervention and the exogenous variables $x_{1 t}$ and $x_{2 t}$ :

$$
\begin{aligned}
& {\left[\begin{array}{cc}
1 & -\beta \\
-\delta & 1
\end{array}\right]\left[\begin{array}{c}
\Delta S_{t} \\
I_{t}
\end{array}\right]=} \\
& {\left[\begin{array}{ll}
a_{11} & a_{12} \\
a_{21} & a_{22}
\end{array}\right]\left[\begin{array}{c}
\Delta S_{t-1} \\
I_{t-1}
\end{array}\right]+\left[\begin{array}{ll}
b_{11} & b_{12} \\
b_{21} & b_{22}
\end{array}\right]\left[\begin{array}{l}
x_{1 t} \\
x_{2 t}
\end{array}\right]+\left[\begin{array}{l}
c_{r} \\
C_{I}
\end{array}\right]+\left[\begin{array}{l}
u_{r t} \\
u_{I t}
\end{array}\right],}
\end{aligned}
$$

where $\mathrm{E}\left[u u^{\prime}\right]=\Omega .{ }^{13}$ In this system, $\beta$ governs the contemporaneous reaction of exchange rate

\footnotetext{
${ }^{13}$ This equation ignores the nonlinear nature of intervention. This feature of the data will be discussed later.
} 
returns to intervention and $\delta$ governs the reaction of intervention to exchange rate returns.

The simultaneous determination of exchange rate returns and intervention will generate the most immediate problem—acknowledged by most researchers-in inferring the effects of intervention on exchange rates: A simple regression of exchange rate returns on contemporaneous intervention will produce inconsistent estimates of $\beta$ because intervention will be correlated with the estimated error:

[T] he issue of endogeneity arises in our study (and every intervention study) since the central bank usually takes its cue to intervene on the basis of observed exchange rate movements.

(Fatum and Hutchison, 2003b, p. 392)

The most common method to deal with this simultaneity is to use an instrumental variables procedure. To estimate $\beta$ consistently, one would find an instrument for intervention-a variable correlated with intervention but uncorrelated with the shock to exchange rates-and perform a two-stage least squares or a similar instrumental variables procedure.

A slightly subtler problem is that equation (8) contains more structural parameters- $\beta, \delta$, $a_{11}, a_{12}, a_{21}, a_{22}, b_{11}, b_{12}, b_{21}, b_{22}, c_{r}, c_{I}, \Omega_{11}, \Omega_{12}$, $\Omega_{22}$, (15)—than moments estimable from the reduced form (13):

$$
\left[\begin{array}{c}
\Delta S_{t} \\
I_{t}
\end{array}\right]=\frac{1}{1-\beta \delta}\left[\begin{array}{l}
{\left[\begin{array}{ll}
a_{11}+a_{21} \beta & a_{12}+a_{22} \beta \\
\delta a_{11}+a_{21} & a_{12} \delta+a_{22}
\end{array}\right]\left[\begin{array}{c}
\Delta S_{t-1} \\
I_{t-1}
\end{array}\right]} \\
+\left[\begin{array}{ll}
b_{11}+b_{21} \beta & b_{12}+b_{22} \beta \\
\delta b_{11}+b_{21} & b_{12} \delta+b_{22}
\end{array}\right]\left[\begin{array}{c}
x_{1 t} \\
x_{2 t}
\end{array}\right] \\
+\left[\begin{array}{l}
c_{r}+\beta c_{I} \\
\delta c_{r}+c_{I}
\end{array}\right]+\left[\begin{array}{l}
u_{r t}+\beta u_{I t} \\
\delta u_{r t}+u_{I t}
\end{array}\right]
\end{array}\right] \cdot{ }^{4}
$$

The fact that there are more parameters in the structural system than moments estimable from the reduced form means that some of the structural parameters are not identified.

Simultaneity can contribute to a failure of

\footnotetext{
${ }^{14}$ If intervention is modeled as a limited dependent variable that takes non-zero values only when its determinants exceed some threshold, the reduced form actually depends on whether intervention takes the value zero or not. The reduced form in (9) is true for non-zero values of intervention.
}

identification. For example, if $\beta$ were equal to zero-intervention does not cause returns-then all the structural parameters of the returns equation would be identified, but one would still not be able to uniquely identify $\delta$ and the structural shocks' covariance $\left(\Omega_{12}\right)$. Simultaneity requires specific estimation methods to obtain consistent estimates of parameters; identification means that some estimation methods can consistently estimate the parameters.

\section{Structural Breaks as a Source of Identification}

The usual way to achieve identification is to restrict the structural parameters in a way that allows one to uniquely solve for those parameters from the estimable moments. For example, one might assume that certain regressors don't appear in some equations in a system-which restricts their structural coefficient to be zero-or that certain endogenous variables do not affect each other contemporaneously.

Identification can also be achieved in less traditional ways, however. Changes in the structure of the economy can also offer sources of information that help to identify structural parameters. ${ }^{15}$ For example, Kearns and Rigobon (2005) take advantage of the fact that both the Japanese and Australian authorities changed their intervention procedures to make intervention larger but less frequent. In other words, thresholds for intervention increased.

\section{Can Instability Be Exploited To Achieve Identification?}

The use of structural breaks to identify structural parameters is potentially dangerous, however, because such exercises might be subject to the Lucas critique. ${ }^{16}$ Lucas (1976) argued that evaluating alternative policies using reduced-

\footnotetext{
${ }^{15}$ Other sorts of variation in the data can also be used to identify models. Rigobon and Sack (2003), for example, take advantage of heteroskedasticity in stock market returns to measure the reaction of monetary policy to the stock market.

${ }^{16}$ Noting that the Kearns and Rigobon (2005) study is potentially subject to the Lucas critique is not a particularly damning criticism of their work. Even studies, such as that of Kearns and Rigobon (2005), that pay careful attention to identification must make simplifying assumptions about the structure of the economy. Such assumptions are almost always subject to some criticism.
} 
form econometric models would often produce misleading results because such policies would produce different expectations and different behavior. That is, reduced-form models are not stable when the rules of the economy change.

In the present context, central bank intervention functions are notoriously unstable over time, meaning that the structural parameters of an econometric model—e.g., (8)—might not be stable when the economic environment changes. Estimation of an intervention model will provide results that are specific to the size of the market and intervention and the nature of the reaction function, including the purpose of intervention. Intuitively, the signaling channel depends on intervention signaling future monetary policy or coordinating expectations. If intervention is instead conducted randomly, then it will contain no information and will not influence exchange rates.

Although Kearns and Rigobon (2005) exploit the instability of Japanese and Australian reaction functions to identify their model, instability is an unacknowledged problem for many studies of central bank intervention. If the rules for how intervention is conducted change-as they frequently do-the structural and reduced-form parameters will generally change too.

\section{Event Studies vs. the Structural System}

An event study is essentially a single-equation model that looks at the contemporaneous interaction of intervention and exchange rates. One can use single-equation methods to examine the effects of intervention on exchange rates, but this doesn't rescue the econometrician from making assumptions about the structure of the economy-though it often hides those assumptions. For example, suppose that one investigated the effect of intervention on exchange rate returns by estimating the following single-equation regression by ordinary least squares (OLS):

$$
\Delta S_{t}=C_{r}+\beta I_{t}+A x_{1 t}+e_{t},
$$

where $\Delta S_{t}, x_{1 t}$, and $I_{t}$ are defined as before. When does an event study correctly estimate the structural impact of intervention on returns?

\section{Daily Event Studies and Simultaneity}

The first problem to note is that OLS estimates of $\beta$ would suffer from simultaneous equations bias, unless exchange rate returns did not affect intervention contemporaneously $(\delta=0)$ and the structural errors were uncorrelated. Such assumptions might be tenable in the very-high-frequency (intraday) event studies of Fischer and Zurlinden (1999), Beattie and Fillion (1999), Payne and Vitale (2003), Pasquariello (2002), and Dominguez (2003a,b). But they are certainly not tenable with the daily data needed to determine longer-term responses.

To correct for simultaneous equations bias, some researchers would use an instrumentalvariables procedure, such as two-stage least squares (TSLS), to estimate (1). But this would require instruments that are reliably correlated with $I_{t}$ but not with $\Delta S_{t}$. Such instruments are difficult to find because foreign exchange intervention policy is determined by factors that could well affect $\Delta S_{t}$. And using such instruments to estimate the effect of $I_{t}$ on $\Delta S_{t}$ implicitly constitute identification restrictions because one must exclude the instruments from the structural form of the $\Delta S_{t}$ equation. If the instrument could not be excluded from the $\Delta S_{t}$ equation, then the estimated TSLS coefficient would be an inconsistent estimate of $\beta$. Unfortunately, the identifying restrictions used in single-equation models are very rarely explicitly thought out or discussed, leaving it to the reader to determine what they are and whether they are appropriate.

Finding good instruments is important. The literature on instrumental variables has shown that weak instruments-those not strongly predictive of the regressor-will provide very poor estimates of the coefficients. To summarize the long literature on choosing instrument sets, one would like a parsimonious instrument set that strongly predicts the regressor. For good distributional results, Stock, Wright, and Yogo (2002) provide a function that specifies desired F-statistics as a function of the number of instruments. For one instrument, they recommend an F-statistic of 10 . 
Some researchers have tried to avoid the simultaneity bias by using the lagged value of intervention as the regressor (Huang and Neun, 2004). This practice will not provide the right answer, however. In the simplest case, with no simultaneity and no other regressors, it would have to be the case that

$$
E\left(r_{t} I_{t}\right)=E\left(r_{t} I_{t-1}\right)
$$

for lagged intervention to provide the correct coefficient for the contemporaneous effect. If one assumes a simple linear model for intervention $\left(I_{t}=\rho I_{t-1}+\varepsilon_{t}\right)$, then (10) can hold only if intervention is a martingale $(\rho=1)$, but this conflicts with the mild positive autocorrelation in intervention. ${ }^{17}$ Further, if intervention were an integrated process $(\rho=1)$, then a regression of exchange rate returns $(I(0))$ on intervention $(I(1))$ would be inappropriate because the residuals could not be stationary. Using lagged intervention as the regressor can only properly estimate the response to past intervention, not contemporaneous intervention. It does not resolve simultaneity.

It is worth noting that event studies that eschew regression analysis do not avoid the simultaneity problem, as acknowledged by Fatum and Hutchison (2003b). Whether one actually estimates a regression or uses a nonparametric technique such as the matched sample test or Humpage's discrete distribution methods, if intervention and exchange rates influence each other within the day, then one cannot estimate the impact of intervention on exchange rates $(\beta)$ consistently, unless one uses appropriate assumptions and estimation methods.

To see such bias, consider a system in which intervention and exchange rates are determined simultaneously and the errors are jointly normalfor tractability. For simplicity, assume that the intervening authority leans against the wind but responds to nothing else:

$$
\left[\begin{array}{cc}
1 & -\beta \\
-\delta & 1
\end{array}\right]\left[\begin{array}{c}
\Delta S_{t} \\
I_{t}
\end{array}\right]=\left[\begin{array}{l}
u_{r t} \\
u_{I t}
\end{array}\right] .
$$

\footnotetext{
${ }^{17}$ A martingale process is one whose conditional expectation at $t+1$
} is the value of the variable at $t: E_{t}(Z(t+1))=Z(t)$.
The reduced form for this relation will be

$$
\left[\begin{array}{c}
\Delta S_{t} \\
I_{t}
\end{array}\right]=\frac{1}{1-\beta \delta}\left[\begin{array}{c}
u_{r t}+\beta u_{I t} \\
\delta u_{r t}+u_{I t}
\end{array}\right] .
$$

And, under the null that intervention has no effect on exchange rates $(\beta=0)$ and that the structural shocks are uncorrelated $\left(\sigma_{r I}=0\right),\left(\Delta S_{t}, I_{t}\right)$ are jointly normal with correlation

$$
\rho=\frac{\delta \sigma_{r}^{2}}{\sqrt{\sigma_{r}^{2}\left(\delta^{2} \sigma_{r}^{2}+\sigma_{I}^{2}\right)}}=\frac{\delta \sigma_{r}}{\sqrt{\left(\delta^{2} \sigma_{r}^{2}+\sigma_{I}^{2}\right)}}
$$

and

$$
\left[\begin{array}{c}
\Delta S_{t} \\
I_{t}
\end{array}\right] \sim N\left(\left[\begin{array}{l}
0 \\
0
\end{array}\right],\left[\begin{array}{cc}
\sigma_{r}^{2} & \delta \sigma_{r}^{2} \\
\delta \sigma_{r}^{2} & \delta^{2} \sigma_{r}^{2}+\sigma_{I}^{2}
\end{array}\right]\right) .
$$

The conditional expectation of $\Delta S_{t} \mid I_{t}$ is a well-known property of the bivariate normal distribution:

$$
E\left[\Delta S_{t} \mid I_{t}\right]=\rho \frac{\sigma_{r}}{\sigma_{I}} I_{t}
$$

Humpage's procedure measures the probability of dollar depreciation, conditional on dollar sales (i.e., $\mathrm{P}\left(\Delta S_{t}<0 \mid I_{t}<0\right)$. If $\delta$ is less than zero, as is likely if authorities lean against the wind, then the correlation between intervention and exchange rate returns will be negative $(\rho<0)$. This means that the conditional expectation of the exchange rate return will be positive when the authorities sell dollars $\left(E_{t-1}\left(\Delta S_{t} \mid I_{t}<0\right)>0\right.$, although intervention has no effect on exchange rates. Because the conditional expectation of $\Delta S_{t}$ is positive and the normal distribution is symmetric, the probability of observing a dollar depreciation $\left(\Delta S_{t}<0\right)$ when the authorities sell dollars is less than 50 percent $\left(P\left(\Delta S_{t}<0 \mid I_{t}<0\right)<0.5\right.$, despite the fact that intervention has no effect on exchange rates in this model $(\beta=0)$. An econometrician estimating this probability will find that intervention has fewer successes than one would expect under independence between exchange rates and intervention. This occurs because the intervention reaction function depends on exchange rate changes-the authorities lean against the wind. This example illustrates that simultaneity will bias the estimates of the effect of intervention in 
all event studies, whether they are explicitly regressions or not. ${ }^{18}$

\section{Intraday Studies and Simultaneity}

An advantage of intraday studies is that one can avoid simultaneity under two assumptions: (i) the timing of intervention is measured precisely enough and (ii) the decision interval of the monetary authority is less than the data frequency used. In other words, if one uses 5-minute data, the monetary authority takes at least 5 minutes to react to market developments and intervene. Under these assumptions, there is no contemporaneous impact of exchange rates on intervention and no simultaneity-changes after the intervention are the result of the intervention and not vice versa. This advantage comes at a price, however. If intervention timing is not correctly known, then the effect of intervention will not be estimated correctly. For example, if one assumes that intervention happens before it actually does, then the effect of intervention will appear to be the conditions that prompt intervention. If intervention is thought to occur later than it actually does, then the study will estimate the lagged effect of intervention, which will probably be smaller than the immediate effect. Fischer (2005) implicitly criticizes the reliance on Reuters' reports used by Dominguez (2003a,b) by showing that such reports were fairly inaccurate for Swiss intervention, whose exact times are known.

Although intraday studies of intervention have been tremendously valuable in understanding the immediate impact of intervention for these data, several potential problems remain, aside from timing issues. First, the paucity of periods/ countries for which exact intervention timing is publicly available-only Switzerland over one nine-year period-means that any conclusions from these studies cannot be cross-checked in other samples. Inference could be dangerously fragile. Second, the very short-run effect of intervention might be dominated by transitory effects such as portfolio rebalancing. One cannot rule out

${ }^{18}$ One could argue, of course, that the presence of leaning-againstthe-wind intervention biases tests of the effect of intervention toward finding a perverse effect or no effect and that such tests are therefore conservative. But the important point is that such tests are unreliable for finding the correct answer. the idea that intervention has its full effects over days or weeks. About 40 percent of central bankers surveyed by Neely (2000) believed that intervention takes at least a few days to have its full effect. ${ }^{19}$ Therefore, intraday event studies do not answer the question: What is the dynamic response of the exchange rate to intervention? The next section expands on what is required to correctly answer this question.

\section{Dynamic Impacts}

A correctly estimated regression coefficient describes the static impact of one variable on another. But one would prefer to estimate the dynamic impact on exchange rates of a shock to intervention. That is, a shock to the intervention process will impact exchange rates, which in turn might affect future exchange rates and intervention. In a VAR, the moving average representation summarizes the dynamic impacts of shocks on the variables in the system.

When does an event study estimate the dynamic impact correctly? Correctly estimating the dynamic impact of a shock to intervention on exchange rates requires even more stringent assumptions than correctly estimating the static impact $(\beta)$. All the equations for the endogenous variables in the system (at least exchange rates and intervention) must be correctly estimated, which means identifying all the structural parameters and constructing the dynamic impact of a shock to intervention. The nonlinearity of intervention complicates such an exercise, however.

A friction model can characterize intervention's reaction to explanatory variables such as contemporaneous and past returns and volatility (Rosett, 1959). Such a model permits the dependent variable-intervention-to be insensitive to the independent variables over a range of values. ${ }^{20}$

\footnotetext{
${ }^{19}$ The conclusion that intervention takes hours or days to achieve its full effect contrasts with the finding in the announcement literature that markets fully adjust to announcements within minutes. The secrecy with which intervention is conducted, however, might delay the adjustment.

${ }^{20}$ Rosett (1959) describes the friction model as an extension of the Tobit model (Tobin, 1958). Maddala (1986) provides a very readable introduction to limited dependent-variable models, such as the friction and Tobit models. Almekinders and Eijffinger (1996) used a friction model to study central bank reaction functions.
} 
This is appropriate for a variable like intervention that takes the value zero for a large proportion of observations. The following is a friction model:

$$
\begin{array}{lrr}
I_{t}=\delta \Delta S_{t}+A_{2} X_{2 t}+C_{I}^{-}+u_{I t} & \text { if } & I_{t}<0 \\
I_{t}=0 & \text { if } & I_{t}=0 \\
I_{t}=\delta \Delta S_{t}+A_{2} X_{2 t}-C_{I}^{+}+u_{I t} & \text { if } & I_{t}>0,
\end{array}
$$

where $x_{2 t}$ is a vector of all structural explanatory variables and lags of endogenous variables excluding the constant.

Note that in a friction model the value of the intercept term depends on the sign of intervention. This complicates estimation of the intervention equation and the construction of dynamic impulse responses. The structural model when intervention is positive is as follows:

$$
\left[\begin{array}{cc}
1 & -\beta \\
-\delta & 1
\end{array}\right]\left[\begin{array}{c}
\Delta S_{t} \\
I_{t}
\end{array}\right]=\left[\begin{array}{l}
A_{1} x_{1 t} \\
A_{2} x_{2 t}
\end{array}\right]+\left[\begin{array}{c}
c_{r} \\
-C_{I}^{+}
\end{array}\right]+\left[\begin{array}{l}
u_{r t} \\
u_{I t}
\end{array}\right]
$$

And the model when intervention is negative is the same, except that $-C_{I}^{+}$is replaced by $C_{I}^{-}$.

The reduced form when intervention is positive is as follows:

$$
\left[\begin{array}{c}
\Delta S_{t} \\
I_{t}
\end{array}\right]=\frac{1}{1-\beta \delta}\left[\begin{array}{l}
{\left[\begin{array}{l}
A_{1} x_{1 t}+\beta A_{2} x_{2 t} \\
\delta A_{1} x_{1 t}+A_{2} x_{2 t}
\end{array}\right]} \\
+\left[\begin{array}{l}
c_{r}-\beta C_{I}^{+} \\
\delta c_{r}-c_{I}^{+}
\end{array}\right]+\left[\begin{array}{l}
u_{r t}+\beta u_{I t}^{+} \\
\delta u_{r t}+u_{I t}^{+}
\end{array}\right]
\end{array}\right]
$$

When intervention equals zero, however, the first structural and reduced-form equations coincide as follows:

$$
\Delta S_{t}=A_{1} x_{1 t}+C_{r}+u_{r t} .
$$

And the reduced form for $I_{t}$ implies the following:

$$
\begin{aligned}
& -\delta A_{1} x_{1 t}-A_{2} x_{2 t}-\delta c_{r}-c_{I}^{-}<\delta u_{r t}-u_{I t} \\
& <-\delta A_{1} x_{1 t}-A_{2} x_{2 t}-\delta c_{r}+C_{I}^{+} .
\end{aligned}
$$

Because the reduced form for the exchange rate depends on the value of intervention, the nonlinearity can aid in identification of the structural parameters. Neely (2005b) develops an argument of Sickles and Schmidt (1978) to show that the parameters of the structural exchange rate equation are identifiable without instruments or restricting the structural covariance matrix.

\section{CONCLUSIONS}

This paper selectively reviews and analyzes the recent literature on intervention to suggest areas for further progress. The examination was spurred by two recent trends that have contributed to the study of central bank intervention: (i) the use of high-frequency data and (ii) the event-study methodology. The event-study technique has been motivated by the argument that it is better suited to study the sporadic, clustered intervention process. And high-frequency data seem to mitigate the simultaneity bias plaguing daily studies.

In the context of a selective review of the literature on the effects of interventions, this paper has argued that even nonparametric event studies are still subject to all the econometric problems that beset more conventional econometric procedures. An examination of simultaneity in a nonparametric event study illustrated this point. Event studies will correctly infer the structural effects of intervention only under fairly strong conditions. Recognition of the assumptions explicit in and analysis of the limitations of the procedures are not criticisms of intervention studies. Rather, explicit identification of drawbacks enables researchers to assess results more realistically and improve their procedures.

With respect to structural studies, this paper shows that the effects of intervention in Kim's (2003) rich macroeconomic model are not identified and cautions that the innovative work of Kearns and Rigobon (2005) is potentially subject to the Lucas critique.

Finally, the paper also argues that the nonlinearity of intervention-which has largely been ignored in the literature on the effects of intervention-could be helpful in identifying the effects of intervention and overcoming simultaneity.

\section{REFERENCES}

Aguilar, Javiera and Nydalh, Stefan. "Central Bank Intervention and Exchange Rates: The Case of Sweden." Journal of International Financial Markets, Institutions and Money, September-December 2000, 10(3-4), pp. 303-22. 
Almekinders, Geert J. and Eijffinger, Sylvester C.W. "A Friction Model of Daily Bundesbank and Federal Reserve Intervention." Journal of Banking and Finance, September 1996, 20(8), pp. 1365-80.

Bank for International Settlements. "Foreign Exchange Market Intervention in Emerging Markets: Motives, Techniques and Implications.” BIS Papers, No. 24, Bank for International Settlements, Monetary and Economics Department, May 2005.

Beattie, Neil and Fillion, Jean-François. "An Intraday Analysis of the Effectiveness of Foreign Exchange Intervention." Working Paper 99-4, Bank of Canada, 1999.

Beine, Michel and Laurent, Sebastien. "Central Bank Interventions and Jumps in Double Long Memory Models of Daily Exchange Rates." Journal of Empirical Finance, 2003, 10(5), pp. 641-60.

Beine, Michel; Bos, Charles S. and Laurent, Sebastien. "The Impact of Central Bank FX Interventions on Currency Components.” Unpublished manuscript, March 2005.

Beine, Michel; Laurent, Sebastien and Palm, Franz C. "Central Bank Forex Interventions Assessed Using Realized Moments.” Unpublished manuscript, January 2005.

Bollerslev, Tim. "Generalized Autoregressive Conditional Heteroskedasticity." Journal of Econometrics, April 1986, 31(3), pp. 307-27.

Brandner, Peter; Grech, Harald and Stix, Helmut. "The Effectiveness of Central Bank Intervention in the EMS: The Post 1993 Experience." Working Paper 55, Oesterreichische Nationalbank, December 2001.

Campa, Jose Manuel and Chang, P.H. Kevin. "The Forecasting Ability of Correlations Implied in Foreign Exchange Options." Journal of International Money and Finance, December 1998, 17(6), pp. 855-80.

Castrén, Olli. "Do Options Implied Rnd Functions on G3 Currencies Move Around the Times of Interventions on the JPY/USD Exchange Rate?" Working Paper 410, European Central Bank, 2004.
Chaboud, Alain P. and Humpage, Owen F. "An Assessment of the Impact of Japanese Foreign Exchange Intervention: 1991-2004.” International Finance Discussion Paper No. 824, Board of Governors of the Federal Reserve System, January 2005.

Cross, Sam Y. "All About the Foreign Exchange Market in the United States." Federal Reserve Bank of New York monograph, 1998.

Disyatat, Piti and Galati, Gabriele. "The Effectiveness of Foreign Exchange Intervention in Emerging Market Countries: Evidence from the Czech Koruna." Working Paper 172, Bank for International Settlements, March 2005.

Dominguez, Kathryn. "Foreign Exchange Intervention: Did It Work in the 1990s?" Prepared for "The Dollar" Conference Sponsored by the Institute for International Economics in Washington, DC, September 24, 2002.

Dominguez, Kathryn. "The Market Microstructure of Central Bank Intervention.” Journal of International Economics, January 2003a, 59(1), pp. 25-45.

Dominguez, Kathryn. "When Do Central Bank Interventions Influence Intra-Daily And LongerTerm Exchange Rate Movements?” NBER Working Paper 9875, National Bureau of Economic Research, July 2003b.

Dominguez, Kathryn and Frankel, Jeffery. Does Foreign Exchange Intervention Work? Washington, DC: Institute for International Economics, 1993.

Edison, Hali J. "The Effectiveness of Central-Bank Intervention: A Survey of the Literature After 1982." Special Papers in International Economics No. 18, Princeton University, Department of Economics, 1993.

Edison, Hali J.; Cashin, Paul A. and Liang, Hong. "Foreign Exchange Intervention and the Australian Dollar: Has It Mattered?" Working Paper No. 03/99, International Monetary Fund, May 2003.

Fatum, Rasmus. "Post-Plaza Intervention in the DEM/USD Exchange Rate." Canadian Journal of Economics, August 2002, 35(3), pp. 556-67. 
Fatum, Rasmus. "Daily Effects of Foreign Exchange Intervention: Evidence from Official Bank of Canada Data." Working Paper No. 05-12, Santa Cruz Center for International Economics, March 2005.

Fatum, Rasmus and Hutchison, Michael M. "Effectiveness of Official Daily Foreign Exchange Market Intervention Operations in Japan.” NBER Working Paper 9648, National Bureau of Economic Research, December 2003a (forthcoming in Journal of International Money and Finance).

Fatum, Rasmus and Hutchison, Michael M. "Is Sterilised Foreign Exchange Intervention Effective After All? An Event Study Approach." Economic Journal, April 2003b, 113(487), pp. 390-411.

Fatum, Rasmus and King, Michael R. "Rules versus Discretion in Foreign Exchange Intervention: Evidence from Official Bank of Canada HighFrequency Data.” Working Paper No. 04-24, Santa Cruz Center for International Economics, May 12, 2005.

Fischer, Andreas M. "The Inaccuracy of Reuters Reports for Swiss Interventions." Forthcoming in Journal of International Money and Finance, 2005.

Fischer, Andreas M. and Zurlinden, Mathias. "Exchange Rate Effects of Central Bank Interventions: An Analysis of Transaction Prices." Economic Journal, 1999, 109(458), pp. 662-76.

Fratzscher, Marcel. "On the Long-Term Effectiveness of Exchange Rate Communication and Interventions." Unpublished manuscript, February 2005.

Frenkel, Michael; Pierdzioch, Christian and Stadtmann, Georg. "The Effects of Japanese Foreign Exchange Market Interventions on the Yen/U.S. Dollar Exchange Rate Volatility.” Kiel Working Paper No. 1165, 2003.

Galati, Gabriele; Melick, William and Micu, Marian. "Foreign Exchange Intervention and Expectations: An Empirical Study of the Dollar/Yen Exchange Rate.” Unpublished manuscript, Board of Governors of the Federal Reserve System, International Finance Division, August 2002.
Hamilton, J.D. Time Series Analysis. Princeton, NJ: Princeton University Press, 1994.

Herrera, Ana Maria and Ozbay, Pinar. "A Dynamic Model of Central Bank Intervention: Evidence from Turkey." Unpublished manuscript, Michigan State University, 2005.

Hillebrand, Eric and Schnabl, Gunther. "The Effects of Japanese Foreign Exchange Intervention: GARCH Estimation and Change Point Detection.” Unpublished manuscript, November 2003.

Huang, Zhaodan and Neun, Stephen. "The Effectiveness of FED Intervention in the USD/GM Foreign Exchange Market.” Unpublished manuscript, 2004.

Humpage, Owen F. "Dollar Intervention and the Deutschemark-Dollar Exchange Rate: A Daily TimeSeries Model." Working Paper 8404, Federal Reserve Bank of Cleveland, 1984.

Humpage, Owen F. "Institutional Aspects of U.S. Intervention." Economic Review, Federal Reserve Bank of Cleveland, First Quarter 1994, 30(1), pp. 2-19.

Humpage, Owen F. "U.S. Intervention: Assessing the Probability of Success." Journal of Money Credit and Banking, 1999, 31(4), pp. 731-47.

Humpage, Owen F. "The United States as an Informed Foreign-Exchange Speculator.” Journal of International Financial Markets, Institutions, and Money, September-December 2000, 10(3-4), pp. 287-302.

Humpage, Owen F. "Government Intervention in the Foreign Exchange Market.” Unpublished manuscript, Federal Reserve Bank of Cleveland, February 2004.

Ito, Takotoshi. "Is Foreign Exchange Intervention Effective? The Japanese Experience in the 1990's." NBER Working Paper 8914, National Bureau of Economic Research, April 2002.

Kearns, Jonathan and Rigobon, Roberto. "Identifying the Efficacy of Central Bank Interventions: The Australian Case." Journal of International Economics, May 2005, 66(1), pp. 31-48. 
Kim, Soyoung. "Monetary Policy, Foreign Exchange Intervention, and the Exchange Rate in a Unifying Framework." Journal of International Economics, August 2003, 60(2), pp. 355-86.

Kim, Suk-Joong; Kortian, Tro and Sheen, Jeffrey. "Central Bank Intervention and Exchange Rate Volatility-Australian Evidence." Journal of International Financial Markets Institutions and Money, September-December 2000, 10(3-4), pp. 381-405.

Leahy, Michael P. "The Profitability of US Intervention in the Foreign Exchange Markets." Journal of International Money and Finance, December 1995, 14(6), pp. 823-44.

Lucas, Robert E. Jr. "Econometric Policy Evaluation: A Critique," in Karl Brunner and Alan Meltzer, eds., Carnegie-Rochester Conference Series on Public Policy. Volume 1: The Phillips Curve and Labor Markets. 1976, pp. 19-46.

Maddala, G.S. Limited-Dependent and Qualitative Variables in Econometrics. Paperback reprint Econometric Society Monographs, No. 3. Cambridge: Cambridge University Press, 1986.

Morel, Christophe and Teiletche, Jerome. "Do Interventions in Foreign Exchange Markets Modify Investors' Expectations? The Experience of Japan Between 1992 and 2003.” Working Paper 2005-04, University of Paris Dauphine, January 2005.

Neely, Christopher J. "Technical Analysis and the Profitability of U.S. Foreign Exchange Intervention." Federal Reserve Bank of St. Louis Review, July/ August 1998, 80(4), pp. 3-17.

Neely, Christopher J. "The Practice of Central Bank Intervention: Looking Under the Hood.” Central Banking, November 2000, 11(2), pp. 24-37.

Neely, Christopher J. “The Temporal Pattern of Trading Rule Returns and Central Bank Intervention: Intervention Does Not Generate Technical Trading Rule Profits." Journal of International Economics, 2002, 58(1), pp. 211-32.
Neely, Christopher J. "Identification Failure in a Structural VAR with Intervention: Alternative Identification and Estimation." Unpublished manuscript, Federal Reserve Bank of St. Louis, June 2005a.

Neely, Christopher J. "Identifying the Effects of Central Bank Intervention.” Working Paper 2005031A, Federal Reserve Bank of St. Louis, 2005b.

Neely, Christopher J. "Using Implied Volatility to Measure Uncertainty About Interest Rates,” Federal Reserve Bank of St. Louis Review, May/June 2005c, 87(3), pp. 407-425.

Pasquariello, Paolo. "Informative Trading or Just Noise? An Analysis of Currency Returns, Market Liquidity, and Transactions Costs in Proximity of Central Bank Interventions." Unpublished manuscript, New York University, November 3, 2002.

Payne, Richard and Vitale, Paolo. “A Transaction Level Study of the Effects of Central Bank Intervention on Exchange Rates." Journal of International Economics, December 2003, 61(2), pp. 331-52.

Pierdzioch, Christian and Stadtmann, Georg. "The Effectiveness of the Interventions of the Swiss National Bank-An Event-Study Analysis.” Swiss Journal of Economics and Statistics, June 2004, 140(2), pp. 229-44.

Ramaswamy, Ramana and Samiei, Hossein. "The Yen-Dollar Rate: Have Interventions Mattered?” Working Paper No. 00-95, International Monetary Fund, 2000.

Reitz, Stefan. "Nonlinear Impact of Central Bank Intervention on Exchange Rates?' Unpublished manuscript, Deutsche Bundesbank, September 2005.

Rigobon, Roberto and Sack, Brian. "Measuring the Reaction of Monetary Policy to the Stock Market." Quarterly Journal of Economics, May 2003, 118(2), pp. 639-69.

Rogers, Jeff M. and Siklos, Pierre L. "Foreign Exchange Market Intervention in Two Small Open Economies: The Canadian and Australian Experience." Journal of International Money and Finance, 2003, 22(3), pp. 393-416. 
Rosett, Richard. "A Statistical Model of Friction in Economics.” Econometrica, April 1959, 27(2), pp. 263-67.

Sarno, Lucio and Taylor, Mark P. “Official Intervention in the Foreign Exchange Market: Is It Effective and, If So, How Does It Work?" Journal of Economic

Literature, September 2001, 39(3), pp. 839-68.

Sickles, Robin C. and Schmidt, Peter. "Simultaneous Equations Models with Truncated Dependent Variables: A Simultaneous Tobit Model." Journal of Economics and Business, Fall 1978, 31(1), pp. 11-21.

Smith, Michael; McLennan, Michael and Sheen, Jeffrey. "Joint Estimation of an Endogenous Model of Central Bank Intervention and Foreign Exchange Volatility with Application to Australia, 1983 to 2003." Working Paper ECMT2004-3, University of Sydney School of Economics and Political Science, July 2004.

Stock, James H.; Wright, Jonathan H. and Yogo, Motohiro. "A Survey of Weak Instruments and Weak Identification in Generalized Method of Moments." Journal of Business and Economic Statistics, October 2002, 20(4), pp. 518-29.

Taylor, Mark P. "Is Official Exchange Rate Intervention Effective?" Economica, February 2004, 71(281), pp. 1-11.

Tobin, James. "Estimation of Relationships for Limited Dependent Variables.” Econometrica, January 1958, 26(1), pp. 24-36. 


\section{APPENDIX}

Table A1

\begin{tabular}{|c|c|c|c|c|}
\hline Paper & Authority(s) & Period & FX rates & Frequency \\
\hline $\begin{array}{l}\text { Aguilar, Javiera and Nydalh, Stefan. } \\
\text { "Central Bank Intervention and Exchange } \\
\text { Rates: The Case of Sweden." Journal of } \\
\text { International Financial Markets, Institutions } \\
\text { and Money, September-December 2000, } \\
\text { 10(3-4), pp. 303-22 }\end{array}$ & Sweden & $1993-96$ & $\begin{array}{l}\text { SEK/USD } \\
\text { SEK/DEM }\end{array}$ & Daily \\
\hline $\begin{array}{l}\text { Beattie, Neil and Fillion, Jean-François. } \\
\text { "An Intraday Analysis of the Effectiveness of } \\
\text { Foreign Exchange Intervention." Working } \\
\text { Paper 99-4, Bank of Canada, } 1999\end{array}$ & Canada & $\begin{array}{c}\text { April 12, 1995- } \\
\text { January 30, } 1998\end{array}$ & CAN/USD & 10-minute \\
\hline $\begin{array}{l}\text { Beine, Michel and Laurent, Sebastien. } \\
\text { "Central Bank Interventions and Jumps in } \\
\text { Double Long Memory Models of Daily } \\
\text { Exchange Rates." Journal of Empirical } \\
\text { Finance, 2003, 10(5), pp. 641-60 }\end{array}$ & $\begin{array}{c}\text { Germany } \\
\text { Japan } \\
\text { United States }\end{array}$ & $1980-96$ & $\begin{array}{l}\text { USD/DEM } \\
\text { USD/YEN } \\
\text { USD/FRF } \\
\text { USD/GBP }\end{array}$ & Daily \\
\hline $\begin{array}{l}\text { Beine, Michel; Bos, Charles S. and } \\
\text { Laurent, Sebastien. "The Impact of Central } \\
\text { Bank FX Interventions on Currency } \\
\text { Components." Unpublished manuscript, } \\
\text { March } 2005\end{array}$ & $\begin{array}{l}\text { ECB } \\
\text { Germany } \\
\text { Japan } \\
\text { United States }\end{array}$ & 1989-2003 & $\begin{array}{l}\text { EUR/USD } \\
\text { JPY/USD } \\
\text { GBP/USD }\end{array}$ & $\begin{array}{c}\text { Hourly returns } \\
\text { aggregated to } \\
\text { daily returns }\end{array}$ \\
\hline $\begin{array}{l}\text { Beine, Michel; Laurent, Sebastien and } \\
\text { Palm, Franz C. "Central Bank Forex } \\
\text { Interventions Assessed Using Realized } \\
\text { Moments." Unpublished manuscript, } \\
\text { January } 2005\end{array}$ & $\begin{array}{l}\text { ECB } \\
\text { Germany } \\
\text { Japan } \\
\text { United States }\end{array}$ & 1989-2001 & $\begin{array}{l}\text { DEM/USD } \\
\text { JPY/USD }\end{array}$ & $\begin{array}{c}\text { Hourly returns } \\
\text { aggregated to } \\
\text { daily returns }\end{array}$ \\
\hline $\begin{array}{l}\text { Brandner, Peter; Grech, Harald and } \\
\text { Stix, Helmut. "The Effectiveness of } \\
\text { Central Bank Intervention in the EMS: } \\
\text { The Post } 1993 \text { Experience." Working } \\
\text { Paper 55, Oesterreichische Nationalbank, } \\
\text { December } 2001\end{array}$ & $\begin{array}{l}\text { Belgium } \\
\text { Denmark } \\
\text { Spain } \\
\text { France } \\
\text { Ireland } \\
\text { Portugal }\end{array}$ & $\begin{array}{l}\text { August 1993- } \\
\text { April } 1998\end{array}$ & $\begin{array}{l}\text { BEF/DEM } \\
\text { DKK/DEM } \\
\text { ESP/DEM } \\
\text { FRF/DEM } \\
\text { IEP/DEM } \\
\text { PTE/DEM }\end{array}$ & Daily \\
\hline
\end{tabular}


Type of study

Time-series event

\section{Excerpt from abstract or conclusion}

Some support is found for the idea that interventions affect the exchange-rate level during certain sub periods but, overall, the results are weak. Furthermore, in line with the findings for other countries, little empirical support is found for the hypothesis that central bank intervention systematically decreases exchange rate volatility.
Time-series event
[T]he stabilizing effect of expected intervention came into play as the Canadian dollar approached the upper or lower limits of the band. When the dollar exceeded the band, actual intervention did not have any direct impact because it was expected. Moreover, the results show that discretionary (or unexpected) intervention might have been effective in stabilizing the Canadian dollar, although the impact of an intervention sequence diminished as it increased beyond a few days.

Introducing a time-varying jump probability associated to central bank interventions, we find that the central bank interventions, conducted in either a coordinated or unilateral way, induce a jump in the process and tend to increase exchange rate volatility.

Time-series event

We identify the currency components of the mean and the volatility processes of exchange rates using the recent Bayesian framework developed by Bos and Shephard (2004). Our results show that in general, the concerted interventions tend to affect the dynamics of both currency components of the exchange rate. In contrast, unilateral interventions are found to primarily affect the currency of the central bank present in the market. Our findings also emphasise some role for interventions conducted by these central banks on other related FOREX markets.

Time-series event

The analysis confirms previous empirical findings of an increase of volatility after a co-ordinated $\mathrm{CBI}$. It highlights new findings on the timing and the persistence of co-ordinated interventions on exchange rate volatility, on important volatility spillovers, on the impact on exchange rate covariances and correlations and on skewness coefficients. The empirical findings are partly in line with the predictions of a theoretical model for central bank interventions developed by Vitale (1999).

Time-series event

The results from the EGARCH models show that interventions influenced the conditional mean in only one case. Both volatility increasing and decreasing effects are found for the conditional variance. In the MS-ARCH model more effects on the mean are found. If significant, intervention tends to affect the level of the six ERM I exchange rates only in periods of low and medium volatility. For the conditional variance more volatility decreasing than increasing effects are found. Overall, given our approaches (EGARCH and MS-ARCH), the results show that even in the same institutional framework, intervention does not seem to affect the means and variances in a consistent and predictable manner. 


\section{Table A1, cont'd}

\begin{tabular}{|c|c|c|c|c|}
\hline Paper & Authority(s) & Period & FX rates & Frequency \\
\hline $\begin{array}{l}\text { Castrén, Olli. “Do Options Implied Rnd } \\
\text { Functions on G3 Currencies Move Around } \\
\text { the Times of Interventions on the JPY/USD } \\
\text { Exchange Rate?" Working Paper 410, }\end{array}$ & $\begin{array}{c}\text { Japan } \\
\text { United States }\end{array}$ & $\begin{array}{l}\text { April 2, 1992- } \\
\text { December } 2003\end{array}$ & $\begin{array}{l}\text { JPY/USD } \\
\text { USD/EUR } \\
\text { JPY/USD }\end{array}$ & Daily \\
\hline
\end{tabular}

European Central Bank, 2004

Chaboud, Alain P. and Humpage, Owen F. "An Assessment of the Impact of Japanese Foreign Exchange Intervention: 1991-2004." International Finance Discussion Paper No. 824, Board of Governors of the Federal Reserve System, January 2005

$\begin{array}{lll}\text { Japan } & \text { 1991-2002 USD/JPY Daily }\end{array}$

Disyatat, Piti and Galati, Gabriele. "The Effectiveness of Foreign Exchange Intervention in Emerging Market Countries: Evidence from the Czech Koruna." Working Paper 172, Bank for International Settlements, March 2005

Dominguez, Kathryn. "Foreign Exchange Intervention: Did It Work in the 1990s?" Prepared for "The Dollar" Conference Sponsored by the Institute for International Economics in Washington, DC, September 24, 2002

\begin{tabular}{|c|c|}
\hline $\begin{array}{l}\text { Czech } \\
\text { Republic }\end{array}$ & $\begin{array}{cc}\text { September 2001- } & \text { Czech Koruna/ } \\
\text { October } 2002 & \text { EUR }\end{array}$ \\
\hline
\end{tabular}

\begin{tabular}{|c|c|c|c|c|}
\hline $\begin{array}{l}\text { Dominguez, Kathryn. "The Market } \\
\text { Microstructure of Central Bank Intervention." } \\
\text { Journal of International Economics, 2003a, }\end{array}$ & $\begin{array}{l}\text { United States } \\
\text { Germany } \\
\text { Japan }\end{array}$ & 1987-95 & $\begin{array}{l}\text { JPY/USD } \\
\text { DEM/USD }\end{array}$ & 5-minute \\
\hline
\end{tabular}
59(1), pp. 25-45

\begin{tabular}{|c|c|c|c|}
\hline $\begin{array}{c}\text { ECB } \\
\text { Germany } \\
\text { Japan }\end{array}$ & $1990-2002$ & $\begin{array}{l}\text { JPY/USD } \\
\text { DEM/USD }\end{array}$ & $\begin{array}{c}\text { Four-hour/ } \\
\text { daily }\end{array}$ \\
\hline
\end{tabular}

United States

59(1), pp. 25-45

Dominguez, Kathryn. "When Do Central Bank Interventions Influence Intra-Daily and Longer-Term Exchange Rate Movements?" NBER Working Paper 9875, National Bureau of Economic Research, July 2003b

\begin{tabular}{|c|c|c|c|}
\hline $\begin{array}{l}\text { United States } \\
\text { Germany } \\
\text { Japan }\end{array}$ & $\begin{array}{l}69 \text { days for } \\
\text { USD/DEM and } \\
66 \text { days for } \\
\text { JPY/USD over } \\
\text { August 1989- } \\
\text { August } 1995\end{array}$ & $\begin{array}{l}\text { USD/DEM } \\
\text { JPY/USD }\end{array}$ & Tick-by-tick \\
\hline
\end{tabular}


Type of study

Time-series event
Excerpt from abstract or conclusion

[I]nterventions on the JPY/USD exchange rate coincide with systematic changes in all moments of the estimated risk-neutral density functions (RNDs) on the JPY/USD currency pair, and in several of the moments of the estimated RNDs on the JPY/EUR and USD/EUR currency pairs. In particular, the operations where Japanese yen is sold coincide with a movement in the mean of the RND towards a weaker yen both against the US dollar and the euro, as well as with an increase in implied standard deviations. Prior to the interventions, the RNDs tend to move into opposite directions suggesting, on the average, increasingly unfavourable market conditions and leaning-against-the wind by the Japanese authorities.
Other event

Time-series event
The effectiveness of Japanese interventions over the past decade depended in large part on the frequency and size of the transactions. Prior to June 1995, Japanese interventions only had value as a forecast that the previous day's yen appreciation or depreciation would moderate during the current day. After June 1995, Japanese purchases of dollars had value as a forecast that the yen would depreciate. Probit analysis confirms that large, infrequent interventions, which characterized the later period, had a higher likelihood of success than small, frequent interventions.

We find that central bank intervention had some (weakly) statistically significant impact on the spot rate and the risk reversal but that this impact was small. We do not find evidence that intervention had an influence on short-term exchange rate volatility. We also find that, in our sample period, Czech authorities appeared to intervene mainly in response to an acceleration of the speed of koruna appreciation.

Time-series event/ other event
This study examines the intervention operations of the G3 countries (the United States, Japan and Germany) over the period 1990 through 2002. I analyze the very short-term (four-hour) effects of G3 intervention operations on dollar exchange rates, as well as the longer-term correlations between episodes of intervention and subsequent currency movements. The more recent G3 intervention data suggest that intervention policy is both alive and well-G3 central banks continue to intervene to influence currency valuesand these interventions were often successful in influencing short- and longer-term exchange rate movements.

Time-series event

[S]ome traders typically know that the Fed is intervening at least one hour prior to the public release of the information in newswire reports. Also, the evidence suggests that the timing of intervention operations matters-interventions that occur during heavy trading volume and that are closely timed to scheduled macro announcements are the most likely to have large effects. Finally, results indicate that interventions that are coordinated with another central bank are more likely to be effective than are unilateral interventions.

Time-series event

Using intra-daily and daily exchange rate and intervention data, the paper analyzes the influence of interventions on exchange rate volatility, finding evidence of both within day and daily impact effects, but little evidence that interventions increase longer-term volatility. 


\section{Table A1, cont'd}

\begin{tabular}{|c|c|c|c|c|}
\hline Paper & Authority(s) & Period & FX rates & Frequency \\
\hline $\begin{array}{l}\text { Edison, Hali J.; Cashin, Paul A. and } \\
\text { Liang, Hong. "Foreign Exchange } \\
\text { Intervention and the Australian Dollar: } \\
\text { Has It Mattered?" Working Paper No. 03/99, } \\
\text { International Monetary Fund, May } 2003\end{array}$ & Australia & $\begin{array}{l}\text { January 1984- } \\
\text { December } 2001\end{array}$ & AUD/USD & Daily \\
\hline
\end{tabular}

\begin{tabular}{|c|c|c|c|}
\hline $\begin{array}{l}\text { Fatum, Rasmus. "Post-Plaza Intervention } \\
\text { in the DEM/USD Exchange Rate." Canadian } \\
\text { Journal of Economics, 2002, 35(3), pp. 556-67 }\end{array}$ & $\begin{array}{c}\text { Germany } \\
\text { United States }\end{array}$ & $\begin{array}{l}\text { September 1, 1985- } \\
\text { December 31, } 1995\end{array}$ & DEM/USD \\
\hline
\end{tabular}

\begin{tabular}{|c|c|c|c|c|}
\hline $\begin{array}{l}\text { Fatum, Rasmus. "Daily Effects of Foreign } \\
\text { Exchange Intervention: Evidence from } \\
\text { Official Bank of Canada Data." Working Paper } \\
\text { No. 05-12, Santa Cruz Center for International } \\
\text { Economics, March } 2005\end{array}$ & Canada & $\begin{array}{l}\text { January 1995- } \\
\text { September } 1998\end{array}$ & CAD/USD & Daily \\
\hline
\end{tabular}

\begin{tabular}{|c|c|c|c|c|}
\hline $\begin{array}{l}\text { Fatum, Rasmus and Hutchison, Michael M. } \\
\text { "Effectiveness of Official Daily Foreign } \\
\text { Exchange Market Intervention Operations in } \\
\text { Japan." NBER Working Paper 9648, National } \\
\text { Bureau of Economic Research, 2003a } \\
\text { (forthcoming in Journal of International Money } \\
\text { and Finance) }\end{array}$ & Japan & $\begin{array}{c}\text { April 1, 1991- } \\
\text { December 31, } 2000\end{array}$ & USD/JPY & Daily \\
\hline
\end{tabular}
Fatum, Rasmus and Hutchison, Michael M. ․ Germany September 1985-95 DEM/USD Daily "Is Sterilised Foreign Exchange Intervention United States Effective After All? An Event Study Approach." Economic Journal, April 2003b, 113(487), pp. 390-411
Fatum, Rasmus and King, Michael R. "Rules versus Discretion in Foreign Exchange Intervention: Evidence from Official Bank of Canada High-Frequency Data." Working Paper No. 04-24, Santa Cruz Center for International Economics, May 12, 2005

\begin{tabular}{|c|c|c|c|}
\hline Canada & $\begin{array}{l}\text { January 1995- } \\
\text { September } 1998\end{array}$ & CAD/USD & 5-minute \\
\hline
\end{tabular}


Type of study

Time-series event/ other event
Excerpt from abstract or conclusion

[O]ver the period 1997-2001, the RBA has had some success in its intervention operations, by moderating the depreciating tendency of the Australian dollar. Second, we investigate the effects of RBA intervention policies on exchange rate volatility over the floating rate period. Our results indicate that intervention operations tend to be associated with an increase in exchange rate volatility, which suggests that official intervention may have added to market uncertainty. Overall, the effects of RBA intervention are quite modest on both the level and the volatility of the Australian dollar exchange rate.

Other event

The results suggest that central banks can, in fact, improve the likelihood of success primarily through coordination and that unilateral intervention conducted by the Bundesbank appears to have been destabilizing. Furthermore, it is shown that relatively infrequent intervention has a higher likelihood of success.

Other event

Bank of Canada intervention was systematically associated with both a change in the direction and a smoothing of the CAD/USD exchange rate. Bank of Canada intervention did not, however, succeed in reducing the volatility of the CAD/USD exchange rate. Additionally, the paper introduces the issue of currency co-movements to the intervention literature. It is shown that the effects of intervention are weakened when adjusting for general currency co-movements against the USD, suggesting that currency co-movements should be taken into account when addressing the effects of central bank intervention aimed at managing a minor currency vis-à-vis a major currency.

Other event

[W]e find strong evidence that sterilized intervention systemically affects the exchange rate in the short-run (less than one month). This result holds even when intervention is not associated with (simultaneous) interest rate changes, whether or not intervention is "secret" (in the sense of no official reports or rumors of intervention reported over the newswires), and against other robustness checks. Large-scale (amounts over \$1 billion) intervention, coordinated with the Bank of Japan and the Federal Reserve working in unison, give the highest success rate.

Other event

Focusing on daily Bundesbank and US official intervention operations, we identify separate intervention 'episodes' and analyse the subsequent effect on the exchange rate. Using the non-parametric sign test and matched-sample test, we find strong evidence that sterilised intervention systemically affects the exchange rate in the short run. This result is robust to changes in event window definitions over the short run and to controlling for central bank interest rate changes during events.

Other event

This paper analyzes official, high-frequency Bank of Canada intervention and exchange rate data (the latter quoted at the end of every 5-minute interval over every 24-hour period) over the January 1995 to September 1998 time-period. The data is of particular interest as it spans over two distinctly different intervention regimes-one characterized by purely rules-based ("mechanistic") intervention versus one characterized by both rules-based and discretionary intervention. This unique feature of the data allows for both a comparison of the effects of rules-based version discretionary intervention and a general investigation of intraday effects of intervention. Employing an event-study methodology and three different criteria for success, the study presents strong evidence showing that intervention systematically affects movements in the CAD/USD and in the desired direction along with some evidence that intervention is associated with a reduction of exchange rate volatility. Interestingly, there is no indication that discretionary intervention is more effective than rules-based intervention. 


\section{Table A1, cont'd}

\begin{tabular}{|c|c|c|c|c|}
\hline Paper & Authority(s) & Period & FX rates & Frequency \\
\hline $\begin{array}{l}\text { Fischer, Andreas M. and Zurlinden, Mathias. } \\
\text { "Exchange Rate Effects of Central Bank } \\
\text { Interventions: An Analysis of Transaction } \\
\text { Prices." Economic Journal, 1999, 109(458), } \\
\text { pp. 662-76 }\end{array}$ & Switzerland & 1986-94 & CHF/USD & $\begin{array}{l}\text { Irregular at } \\
\text { intervention }\end{array}$ \\
\hline $\begin{array}{l}\text { Fratzscher, Marcel. "On the Long-Term } \\
\text { Effectiveness of Exchange Rate } \\
\text { Communication and Interventions." } \\
\text { Unpublished manuscript, February } 2005\end{array}$ & $\begin{array}{l}\text { ECB } \\
\text { Germany } \\
\text { Japan } \\
\text { United States }\end{array}$ & 1990-2003 & $\begin{array}{l}\text { EUR/USD } \\
\text { JPY/USD }\end{array}$ & Daily \\
\hline
\end{tabular}

\begin{tabular}{|c|c|c|c|c|}
\hline $\begin{array}{l}\text { Frenkel, Michael; Pierdzioch, Christian and } \\
\text { Stadtmann, Georg. "The Effects of Japanese } \\
\text { Foreign Exchange Market Interventions on } \\
\text { the Yen/U.S. Dollar Exchange Rate Volatility." } \\
\text { Kiel Working Paper No. 1165, } 2003\end{array}$ & Bank of Japan & 1993-2000 & USD/JPY & Daily \\
\hline $\begin{array}{l}\text { Galati, Gabriele; Melick, William and } \\
\text { Micu, Marian. "Foreign Exchange } \\
\text { Intervention and Expectations: An Empirical } \\
\text { Study of the Dollar/Yen Exchange Rate." } \\
\text { Unpublished manuscript, Board of Governors } \\
\text { of the Federal Reserve System, International } \\
\text { Finance Division, August } 2002\end{array}$ & $\begin{array}{c}\text { Japan } \\
\text { United States }\end{array}$ & $\begin{array}{c}\text { 1993-96, } \\
1997-2000\end{array}$ & USD/JPY & Daily \\
\hline
\end{tabular}

$\begin{array}{lccc}\text { Herrera, Ana Maria and Ozbay, Pinar. } & \text { Turkey } & \text { November 1993- } & \text { Turkish lira/ } \\ \text { "A Dynamic Model of Central Bank } & & \text { December 2003 } & \text { USD } \\ \text { Intervention: Evidence from Turkey." } & & \\ \text { Unpublished manuscript, Michigan State } & & \\ \text { University, 2005 } & & \end{array}$


Type of study

Other event
Excerpt from abstract or conclusion

The paper extends results from earlier studies by using the actual prices of interventions. Based on the fact that all Swiss National Bank interventions are announced, our test exploits the informational differences between interventions and customer transactions. A key finding is that only initial interventions matter; customer transactions and subsequent interventions have no influence.

Time-series event

The paper assesses the strategies and the long-term effectiveness of communication as well as actual interventions. The empirical results for the G3 economies indicate that communication has not only exhibited a significant contemporaneous effect on exchange rates, but also has moved forward exchange rates up to a horizon of six months in the desired direction. Moreover, communication is found to reduce exchange rate volatility and uncertainty whereas actual interventions tend to raise it. Overall this underlines a key difference between these two policy tools and suggests that communication tends to be a fairly effective policy tool over the medium-term.

Time-series event

[T] he interventions of the BoJ increased the volatility of the yen/U.S. dollar exchange rate. We find that the interventions of the BoJ, in particular those interventions not reported in the financial press, were positively correlated with exchange rate volatility.

Time-series event

We estimate probability density functions (PDFs) from option data to describe market expectations. We find that, between 1993 and 1996, Japanese authorities tended to respond mainly to deviations of the exchange rate from some implicit target levels and to a rise in market uncertainty. Between 1997 and 2000, the Bank of Japan mainly reacted in response to higher uncertainty. On the other hand, the Federal Reserve mainly intervened in cooperation with the Bank of Japan. We find that intervention had no statistically significant systematic effect on the mean of dollar/yen expectations. Consistently, we detect no evidence that intervention systematically altered market participants' bias between a stronger and a weaker dollar with respect to the forward rate. Contrary to most findings of the literature, we failed to find evidence that intervention was associated on average with higher exchange rate variability. Finally, we find that intervention was not followed by an increase in the tails of the distribution of exchange rate expectations.

Time-series event

We examine central bank intervention in foreign exchange markets using a dynamic censored regression model. We allow the amount of purchase and sale interventions to depend nonlinearly upon lagged values of intervention and on measures of disorderly foreign exchange markets. Using data for the CBRT, we find persistence in interventions, which suggests the presence of political costs and/or a signal of future monetary policy. We find strong evidence of nonnormality and heteroskedasticity in the Tobit model of the reaction function. Estimation results using Powell's LAD, a robust estimator, reveal the importance of considering these specification issues when modeling central bank intervention. 


\section{Table A1, cont'd}

\begin{tabular}{|c|c|c|c|c|}
\hline Paper & Authority(s) & Period & FX rates & Frequency \\
\hline $\begin{array}{l}\text { Hillebrand, Eric and Schnabl, Gunther. } \\
\text { "The Effects of Japanese Foreign Exchange } \\
\text { Intervention. GARCH Estimation and Change } \\
\text { Point Detection." Unpublished manuscript, } \\
\text { November } 2003\end{array}$ & Japan & 1991-2002 & JPY/USD & Daily \\
\hline $\begin{array}{l}\text { Huang, Zhaodan and Neun, Stephen. } \\
\text { "The Effectiveness of FED Intervention } \\
\text { in the USD/GM Foreign Exchange Market." } \\
\text { Unpublished manuscript, } 2004\end{array}$ & $\begin{array}{c}\text { Germany } \\
\text { United States }\end{array}$ & 1978-95 & USD/DEM & Daily \\
\hline $\begin{array}{l}\text { Humpage, Owen F. "U.S. Intervention: } \\
\text { Assessing the Probability of Success." }\end{array}$ & United States & $\begin{array}{l}\text { February 1987- } \\
\text { February } 1990\end{array}$ & $\begin{array}{l}\text { DEM/USD } \\
\text { JPY/USD }\end{array}$ & Daily \\
\hline
\end{tabular}

Journal of Money, Credit, and Banking, 1999, 31(4), pp. 731-47
Humpage, Owen F. "The United States as an Informed Foreign-Exchange Speculator." Journal of International Financial Markets, Institutions, and Money, 2000, 10(3-4),
pp. 287-302

$\begin{array}{cccc}\text { United States } & \begin{array}{c}\text { September } 23 \text { and } \\ \text { December 31, } 1985\end{array} & \text { DEM/USD } & \text { JPY/USD }\end{array}$
Ito, Takatoshi. "Is Foreign Exchange Intervention Effective? The Japanese
Experience in the 1990's." NBER Working Paper 8914, National Bureau of Economic Research, 2002 $\begin{array}{ll}\text { Japan } & \text { April 1991- } \\ \text { March 2001 }\end{array}$

JPY/USD

Daily 
Type of study

Time-series event
Excerpt from abstract or conclusion

Using newly released daily intervention data, we show that the success of interventions varies over time. Measured on the total sample between 1991 and 2002, interventions had the desired effect on the exchange rate at the cost of higher volatility. From 1991 to 1998 interventions were unsuccessful and coincided with increased exchange rate volatility. Since 1999 interventions yield the intended effect while volatility is lower. This provides evidence for successful intervention in Japan's liquidity trap where the distinction between sterilized and unsterilized intervention becomes blurred.

Other event

Tests based on the daily intervention data of the FED and Bundesbank show that the FED's interventions indeed systematically change the course of the exchange in the short run, and that the direction of the movement is consistent with the central bank's intention. Further, the paper tests the endogeneity problem and argues that it does not jeopardize the conclusions. These findings are important to understand why central banks continue to use intervention as a policy instrument from time to time.

Other event

Results from a logit model suggest that coordinated intervention has a higher probability of success than unilateral intervention. The probability of success also increases with the dollar amount of an intervention. Other conditioning variables are not significant. The paper presents a reaction function, with adjustments for the incidentally truncated nature of intervention data. Predicted values serve as instruments for intervention in the logit models.

Other event

US exchange-market interventions have no direct effect on market fundamentals, but they may influence expectations. If intervention has value as a forecast of exchange-rate movements, knowledge that the United States is trading will cause dealers to alter their prior estimates of the distribution of exchange-rate changes. This paper finds that US intervention has had value only as a forecast that recent exchange-rate movements would moderate. Less than half of the interventions, however, seemed successful, and the favorable results were generally confined to two short periods that were characterized by uncertainty about future Federal Reserve policies.

Time-series event

The Japanese monetary authorities, by buying the dollar low and selling it high, have produced large profits, in terms of realized capital gains, unrealized capital gains, and carrying (interest rate differential) profits, from interventions during the ten years. Profits amounted to 9 trillion yen ( $2 \%$ of GDP) in ten years. Interventions are found to be effective in the second half of the 1990s, when daily yen/dollar exchange rate changes were regressed on various factors including interventions. The US interventions in the 1990s were always accompanied by the Japanese interventions. The joint interventions were found to be 20-50 times more effective than the Japanese unilateral interventions. Japanese interventions were found to be prompted by rapid changes in the yen/dollar rate and the deviation from the long-run mean (say, 125 yen). The interventions in the second half were less predictable than the first half. 


\section{Table A1, cont'd}

\begin{tabular}{|c|c|c|c|c|}
\hline Paper & Authority(s) & Period & FX rates & Frequency \\
\hline $\begin{array}{l}\text { Kearns, Jonathan and Rigobon, Roberto. } \\
\text { "Identifying the Efficacy of Central Bank } \\
\text { Interventions: The Australian Case." } \\
\text { Journal of International Economics, 2005, } \\
66(1), \text { pp. 31-48 }\end{array}$ & $\begin{array}{c}\text { Australia } \\
\text { Japan }\end{array}$ & $\begin{array}{c}\text { Australia: July 1986- } \\
\text { November 1993; } \\
\text { Japan: May 1991- } \\
\text { June } 2002\end{array}$ & $\begin{array}{l}\text { AUD/USD } \\
\text { JPY/USD } \\
\text { JPY/EUR }\end{array}$ & Daily \\
\hline
\end{tabular}

Kim, Soyoung. "Monetary Policy, Foreign Exchange Intervention, and the Exchange Rate in a Unifying Framework." Journal of International Economics, 2003, 60(2), pp. $355-86$
United States

1974-96

Trade-weighted monthly
Monthly (Monthy
Kim, Suk-Joong: Kortian, Tro and Sheen, Jeffrey. "Central Bank Intervention and Exchange Rate Volatility-Australian Evidence." Journal of International Financial Markets Institutions and Money, 2000, 10(3-4), pp. 381-405
Morel, Christophe and Teiletche, Jerome. "Do Interventions in Foreign Exchange Markets Modify Investors' Expectations? The Experience of Japan Between 1992 and 2003." Working Paper 2005-04, University of Paris Dauphine, January 2005
Australia
1983-97
AUD/USD
Daily

$\begin{array}{lll}\text { Australia } & 1983-97 & \text { AUD/USD }\end{array}$

\begin{tabular}{|c|c|c|c|}
\hline Japan & $\begin{array}{c}\text { April 1992- } \\
\text { October } 2003\end{array}$ & JPY/USD & Daily \\
\hline
\end{tabular}

$\begin{array}{cccc}\begin{array}{c}\text { Neely, Christopher J. "Identifying the Effects } \\ \text { of Central Bank Intervention." Working }\end{array} & \text { United States } & 1987-90 & \text { DEM/USD } \\ \text { JPY/USD }\end{array}$
Paper 2005-031A, Federal Reserve Bank of St. Louis, 2005b 
Type of study

Structural

Excerpt from abstract or conclusion

There are three main results. Our point estimates suggest that central bank intervention potentially has an economically and statistically significant contemporaneous effect. For Australia we find a $\$$ US100m purchase of the domestic currency will appreciate the exchange rate by 1.3 to 1.8 per cent. This estimate is similar to that from Dominguez and Frankel (1993c), but larger than previous empirical findings. Our point estimate for Japan is smaller with a $\$$ US100m purchase appreciating the yen by just 0.2 per cent, but interpretation must consider the substantially larger size of interventions conducted by the Bank of Japan. Secondly, the vast majority of the effect of an intervention on the exchange rate is found to occur during the day in which it is conducted, with only a smaller impact on subsequent days. Finally, we confirm that central bank intervention policy can typically be characterized as leaning against the wind.

Structural VAR

The structural VAR model is developed to jointly analyze the effects of foreign exchange intervention and (money or interest rate setting) conventional monetary policy on the exchange rate, the two types of policy reactions to the exchange rate, and interactions between the two types of policies. First, many interactions among the two types of policies and the exchange rate are found, which suggests that a joint analysis is important. Second, foreign exchange intervention has substantial effects on the exchange rate, reacts to the exchange rate significantly (to stabilize the exchange rate), and signals future conventional monetary policy stance changes (to back up the intervention).

Time-series event

We find contemporaneous positive correlation between the direction of intervention and the conditional mean and variance of the exchange rate returns. We show that sustained and large interventions have a stabilising influence in the foreign exchange market in terms of direction and volatility. Without these interventions, the market would have moved further and exhibited more volatility.

Time-series event

The purpose of this paper is to analyze the impact of the Bank of Japan's official interventions on the JPY/USD parity during the period 1992-2003. The novelty of our approach is to combine two recent advances of the empirical literature on foreign exchange interventions: (i) drawing on over-the-counter option prices to characterize more precisely the distribution of market expectations; (ii) redefining interventions in terms of events as they tend to come in clusters. Moreover, in order to deal with the features of the data (small sample size, non-standard distribution), we use bootstrap tests.

Structural VAR

and structural nonlinear

system
Most intervention studies have been silent on the assumed structure of the economic system-implicitly imposing implausible assumptions-despite the fact that inference depends crucially on such issues. This paper proposes to identify the cross-effects of intervention with the level and volatility of exchange rates using the likely timing of intervention, macroeconomic announcements as instruments and the nonlinear structure of the intervention reaction function. Proper identification of the effects of intervention indicates that it is moderately effective in changing the levels of exchange rates but has no significant effect on volatility. The paper also illustrates that such inference depends on paying careful attention to seemingly innocuous identification assumptions. 


\section{Table A1, cont'd}

\begin{tabular}{|c|c|c|c|c|}
\hline Paper & Authority(s) & Period & FX rates & Frequency \\
\hline $\begin{array}{l}\text { Pasquariello, Paolo. "Informative Trading } \\
\text { or Just Noise? An Analysis of Currency } \\
\text { Returns, Market Liquidity, and Transactions } \\
\text { Costs in Proximity of Central Bank } \\
\text { Interventions." Unpublished manuscript, } \\
\text { New York University, November 3, } 2002\end{array}$ & Switzerland & 1986-98 & CHF/USD & 5-minute \\
\hline $\begin{array}{l}\text { Payne, Richard and Vitale, Paolo. "A Transaction } \\
\text { Level Study of the Effects of Central Bank } \\
\text { Intervention on Exchange Rates." Journal of } \\
\text { International Economics, 2003, 61(2), } \\
\text { pp. 331-52 }\end{array}$ & Switzerland & 1986-95 & CHF/USD & 15-minute \\
\hline $\begin{array}{l}\text { Pierdzioch, Christian and Stadtmann, Georg. } \\
\text { "The Effectiveness of the Interventions of } \\
\text { the Swiss National Bank-An Event-Study } \\
\text { Analysis." Swiss Journal of Economics and } \\
\text { Statistics, 2004, 140(2), pp. 229-44 }\end{array}$ & Switzerland & 1986-95 & CHF/USD & Daily \\
\hline $\begin{array}{l}\text { Ramaswamy, Ramana and Samiei, Hossein. } \\
\text { "The Yen-Dollar Rate: Have Interventions } \\
\text { Mattered?" Working Paper No. 00-95, Wall } \\
\text { International Monetary Fund, } 2000\end{array}$ & $\begin{array}{l}\text { Reuters, } \\
\text { ancial Times, and } \\
\text { treet Journal reports } \\
\text { Bank of Japan and } \\
\text {.S. intervention }\end{array}$ & $1995-99$ & JPY/USD & Daily \\
\hline
\end{tabular}

$\begin{array}{lccc}\text { Reitz, Stefan. "Nonlinear Impact of Central } & \text { Germany } & 1980 \text { and } 1992 & \text { USD/DEM } \\ \text { Bank Intervention on Exchange Rates?" } & \text { United States } & & \text { Daily } \\ \text { Unpublished manuscript, Deutsche } & & \\ \text { Bundesbank, September 2005 } & & \end{array}$


Type of study

Time-series event
Excerpt from abstract or conclusion

We find that the effectiveness of these trades is crucially related to their perceived information content, rather than to imperfect substitutability or inventory considerations. Indeed, regardless of their size, only SNB interventions (especially when unexpected or inconsistent with market momentum) had significant and persistent effects on daily CHF/USD returns, although they often failed to smooth currency fluctuations. Unsuccessful transactions instead induced the greatest misinformation and heterogeneity of beliefs among market participants and reduced market liquidity. These changes always translated into higher, economically significant transaction costs borne by the population of investors.
Other event
Using an event study approach we find that intervention has important short-run effects on exchange rate returns. In particular, among various results, we find that i) intervention has a stronger impact when the SNB moves with-the-market and when its activity is concerted with that of other central banks and ii) exchange rate returns move in the 15 min interval prior to interventions.

We find some evidence that the interventions of the SNB had an impact on exchange rate dynamics. The significance of this effect, however, depends on the direction of intervention. In general, the evidence suggests that the interventions of the SNB to strengthen the Swiss franc were more effective than its interventions to weaken the Swiss franc. We also find that the results of the tests for the effectiveness of the interventions of the SNB depend upon the length of the pre- and post-event window analyzed.
Time-series event
Using daily data for 1995-99, this paper estimates a simple forward looking model of the exchange rate to show that foreign exchange interventions have, on the whole, had small but persistent effects on the yen-dollar rate. Contrary to conventional wisdom, sterilized interventions have mattered. Consistent with conventional wisdom, coordinated interventions have a higher probability of success and move the yen-dollar rate by a larger margin than unilateral interventions. A probit model indicates that both an excessive appreciation and depreciation of the yen provoke interventions, and that interventions occur in clusters - if there is one today, there will likely be another tomorrow.

Time-series event

In this paper we study a relatively new route of effectiveness of central bank intervention as proposed by Sarno and Taylor (2001). According to their argumentation strong and persistent misalignments of the exchange rate are due to a weakening of stabilizing speculation. Of course, the more the exchange rate deviates from purchasing power parity (ppp) the larger the cumulative losses associated with speculation based on ppp so that stabilizing speculators tend to leave the market. In such circumstances, intervention operations of central banks may encourage their re-entry into the market. Applying daily Federal Reserve intervention data from 1980 to 1992 we find that the dollar/ mark exchange rate's reversion to ppp depends nonlinearly on the amount of intervention operations and the degree of misalignment. The empirical results suggest that the FED's interventions have been effective by increasing speculators' confidence in the validity of ppp. 


\section{Table A1, cont'd}

\begin{tabular}{|c|c|c|c|c|}
\hline Paper & Authority(s) & Period & FX rates & Frequency \\
\hline $\begin{array}{l}\text { Rogers, Jeff M. and Siklos, Pierre L. } \\
\text { "Foreign Exchange Market Intervention } \\
\text { in Two Small Open Economies: The } \\
\text { Canadian and Australian Experience." } \\
\text { Journal of International Money and Finance, } \\
\text { 2003, 22(3), pp. 393-416 }\end{array}$ & $\begin{array}{l}\text { Canada } \\
\text { Australia }\end{array}$ & 1989-98 & $\begin{array}{l}\text { AUD/USD } \\
\text { CAD/USD }\end{array}$ & Daily \\
\hline $\begin{array}{l}\text { Smith, Michael; McLennan, Michael and } \\
\text { Sheen, Jeffrey. "Joint Estimation of an } \\
\text { Endogenous Model of Central Bank } \\
\text { Intervention and Foreign Exchange Volatility } \\
\text { with Application to Australia, } 1983 \text { to 2003." } \\
\text { Working Paper ECMT2004-3, University of } \\
\text { Sydney School of Economics and Political } \\
\text { Science, July } 2004\end{array}$ & Australia & 1983-2003 & AUD/USD & Daily \\
\hline
\end{tabular}

\footnotetext{
Taylor, Mark P. “Is Official Exchange Rate Intervention Effective?" Economica, 2004, 71, pp. 1-11
}

\begin{tabular}{|c|c|c|}
\hline $\begin{array}{c}\text { Germany } \\
\text { United States }\end{array}$ & $\begin{array}{c}\text { August 1985- } \\
\text { December } 1998\end{array}$ & USD/DEM \\
\hline
\end{tabular}


Type of study

Time-series event

\section{Excerpt from abstract or conclusion}

Both central banks intervene in response to excessive exchange rate volatility and uncertainty. Volatility is the implied volatility of foreign currency futures options. Uncertainty is the kurtosis of the implied risk-neutral probability density functions. We also examine the impact of inflation targets. Unlike other studies we also consider commodity futures prices. These turn out to help explain the effectiveness of intervention. Central bank intervention was largely unsuccessful in both countries though volatility and kurtosis were modestly affected.

Time-series event

A stochastic volatility model with jumps is employed for the exchange rate, while a threshold model is used for intervention. The jump and latent volatility processes in the stochastic volatility model and latent intervention in the threshold model, are endogenous. To account for this, both models are estimated jointly using Markov chain Monte Carlo (MCMC). The model is applied to the analysis of intervention by the Reserve Bank of Australia (RBA) in the Australian/US dollar exchange rate from 1983 to 2003... The empirical work suggests that RBA intervention is partially precipitated by volatility in the foreign exchange rate. However, RBA intervention appears to have exacerbated contemporaneous volatility between 1983 and 1993, but has since avoided having any effect. Analysis of lagged volatility suggests one reason may be improved targeting of intervention to address contemporaneous volatility, as opposed to volatility occurring on previous trading days. The RBA does not appear to respond to jumps identified in the exchange rate.

Time-series event

I examine the effectiveness of exchange rate intervention within the context of a Markovswitching model for the real exchange rate. The probability of switching between stable and unstable regimes depends non-linearly upon the amount of intervention, the degree of misalignment and the duration of the regime. Applying this to dollar-mark data for the period 1985-98, I find that intervention increases the probability of stability when the rate is misaligned, and that its influence grows with the degree of misalignment. Intervention within a small neighbourhood of equilibrium will result in a greater probability of instability. 
